Article

\title{
Assessing the Performance of Sustainable Development Goals of EU Countries: Hard and Soft Data Integration
}

\author{
Ewa Chodakowska *(D) and Joanicjusz Nazarko \\ Faculty of Engineering Management, Bialystok University of Technology, Wiejska 45A, 15-351 Bialystok, Poland; \\ j.nazarko@pb.edu.pl \\ * Correspondence: e.chodakowska@pb.edu.pl
}

Received: 10 June 2020; Accepted: 2 July 2020; Published: 3 July 2020

check for updates

\begin{abstract}
The European Union (EU) energy policy for sustainable development has been the topic of continuous debate, research, and analysis, which frequently focused on objectives and the evaluation of quantitative and qualitative performance. Different approaches can be used for the assessment of sustainable development goals. The authors of the article conducted a literature review of relevant research papers dated 2016-2020. The most common are quantitative methods based on hard data. Some qualitative studies based on soft data are also available but rare. This article proposes hybrid Rough Set Data Envelopment Analysis (DEA) and Rough Set Network DEA models that integrate both approaches. Also, the models allow the inclusion of uncertainty in the underlying data. The article uses hard data of the International Energy Agency (IEA) and the results of the EU survey regarding the influence of the socio-economic environment on $\mathrm{CO}_{2}$ emissions in EU countries. The authors demonstrate that multifaceted and objective assessment is possible by merging concepts from the set theory and operational research.
\end{abstract}

Keywords: rough set; data envelopment analysis (DEA); network DEA; sustainability; EU countries; $\mathrm{CO}_{2}$; qualitative (soft) data; quantitative (hard) data

\section{Introduction}

Energy is the main driver for economic growth; however, it is also the leading cause of $\mathrm{CO}_{2}$ emissions [1]. A shift away from high-carbon energy sources resulted from depleting fossil fuels and the growing awareness of the negative impact made by economic development on the environment. There is a global consensus that energy needs to become eco-friendly [2]. Based on the United Nations Agenda 2030 [3], sustainable development is impossible without "access to affordable, reliable, sustainable, and modern energy for all".

Many economies have set ambitious goals for their energy sectors, emphasizing safety, sustainability, environmental friendliness, resource-efficiency, and low-carbon dependency [4]. The European Union (EU) is especially active in introducing relevant regulatory framework and policies $[5,6]$. Policy instruments for the smarter and more sustainable electricity in the EU include a wide range of directives, strategies, and roadmaps with targets for a low-carbon economy, energy efficiency and renewable resources [4]. At the micro-level, European enterprises are also encouraged to innovate responsibly [7,8] and assess newly-developed technologies [9] considering the intended and unintended environmental and social impact.

Debates, research efforts, and analyses have been focusing on ways to measure and monitor the progress toward sustainability. Indicators commonly used for those purposes show the indivisibility of the relationship between energy and development. Instead of absolute values, the impact made 
by economies on the natural environment is measured by the share of renewable energy in the total final energy consumption, energy intensity per unit of GDP [3], and $\mathrm{CO}_{2}$ per unit of value-added [10]. However, other issues should also be considered. For example, energy sustainability is impossible without sufficient investments in energy efficiency, expressed as a percentage of GDP or direct investments in infrastructure and technology [3]. It is also important to compare the progress of countries considering many aspects of sustainable energy and development as well as find ways to aggregate the final assessment [11-13].

The review of the literature on the performance of sustainable development goals revealed many available approaches. The used methods range from a comparison of simple indicators via multivariate statistical analysis to an adaptation of multicriteria decision-making methods. In particular, the latter - the adaptation of multicriteria decision-making methods-is a rapidly growing research area [14]. However, most efforts are limited to the analysis of hard quantitative data that describe the progress of a country leaving out the context-dependency defined by the soft qualitative data.

Papers that use qualitative data either present it as an evaluation of policies and initiatives transformed into simple dummy variables [15,16], or consider it indirectly as various ranking scores [11]. In some instances, the data is presented as expert opinions [17] or importance weights determined by experts [18]. Qualitative data often contains more information. However, it is also ambiguous.

A dismissal or oversimplification of qualitative information means the rejection of a vast amount of knowledge. The success of a policy to reduce $\mathrm{CO}_{2}$ emissions depends not only on economic prosperity measured by GDP per capita but also on priorities, set directly and indirectly by the public. The significance of both factors is evident in the midst of unprecedented challenges faced by societies, such as the expected recession and global changes resulting from the COVID-19 pandemic.

The suggestion to integrate soft and hard data on the socio-economic environment makes this article original. The proposal is to use different types of data, i.e., social authorization, the readiness for change, the standard of living, and efforts made toward the decoupling of economic growth and carbon emissions. The article offers to use hybrid models, i.e., Rough Set Data Envelopment Analysis (DEA) and Rough Set Network DEA, to deal with uncertainty in the underlying data used for assessing the performance of sustainable development goals in EU countries.

The article has the following structure. First, it provides a solid review of papers issued in 2016-2020 on monitoring and assessing efforts of EU countries toward energy sustainability. In this part, it also indicates methods and goals used as the background for a proposed approach. Next, Rough Set theory, DEA, and network DEA models are used to deal with uncertain data in the case of sustainable development assessment. Then, a case study is discussed, and results of the analysis are presented. The article finishes with conclusions.

\section{Background Literature}

Many research projects originated from the importance of sustainable development and free public access to EU data aggregated at a national level. Table 1 presents the results of the literature review conducted in the Scopus database. The analysis targeted relevant articles that focused on the EU and were published in 2016-2020. The summary below indicates the methods and aims of each research.

Based on the review, the interest in the problem of objective assessment is high and constant. Most papers focused on the results of multidirectional efforts toward sustainable development and the reduction of its negative impact on the environment. Some papers investigated the speed of changes taking place in this area, e.g., the transition to renewable energy sources. 
Table 1. Summary of most relevant 30 papers.

\begin{tabular}{c} 
Author \\
\hline $\begin{array}{c}\text { Bigerna, Bollino, and Micheli } \\
\text { (2016) [19] }\end{array}$ \\
D'Adamo and Rosa (2016) [20] \\
Duscha, Fougeyrollas, Nathani, \\
Pfaff, Ragwitz, Resch, Schade, \\
Breitschopf, and Walz (2016) [21]
\end{tabular}

deLlano-Paz, Fernandez, and Soares (2016) [22]

Pacesila, Burcea, and Colesca (2016) [23]

Cilinskis, Indzere, and Blumberga (2017) [24]

Momete (2017) [12]

Nikolaev and Konidari (2017) [25]

Capros, Kannavou, Evangelopoulou, Petropoulos, Siskos, Tasios, Zazias, and DeVita (2018) [26]
Methods and Main Indicators

Simulation model and general equilibrium model

data: GDP, $\mathrm{CO}_{2}$ emission, RES development targets

Growing steps structure of RE share and average values data: share of RE production and consumption per capita Macroeconomic models: NEMESIS and ASTRA with scenario simulation based on PRIMES

data: $\mathrm{CO}_{2}$ reduction, consumption and import of fossil fuels, GDP, employment, RE deployment, costs related to RE deployment Markowitz portfolio theory data: cost and risk of RES technologies (e.g., production costs investment, GHG emissions, plant accident) from other studies $\mathrm{K}$-means CA

data: renewables data (RES share, RES for heating and cooling, transport, energy dependence

\section{TOPSIS}

data: non-ETS emissions of GHG by different sectors

\section{Composite index of RE development based} on aggregation data: production and consumption mix: fossil fuels oil, gas, coal, solid fuels, nuclear energy, and RES shares LEAP (Long-range Energy Alternatives Planning) and the MCDM AMS (the combination of three standard MCMs: AHP, MAUT and SMART

data: structure of the final energy consumption by fuels, total contribution (capacity, electricity generation) of RES technologies, and policy packages assumptions PRIMES model that simulates energy consumption and the energy supply system

data: GHG emissions, energy efficiency, RES, energy demand, with costs and required investments
To construct a model that identifies and estimates potential costs of non-compliance with RES

targets in some counties; to present a simulation

To assess the EC RES trajectory toward 2020 strategy

To assess whether RES can positively contribute to the objectives of the European energy policy: combating climate change, improving the security of supply and resulting in economic benefits (job creation and economic growth)

To analyze the EU policy framework goals, cost, risk, and security issues

To analyze the RE sector in the EU

To introduce a methodology based on multi-criteria analysis TOPSIS

to policy planning aimed at climate goals using a Latvian example

To investigate the energy development in terms of RE in the Eastern Bloc of the EU

To identify the most feasible level of ambition up to 2030 for the Bulgarian RE policy by simulating three scenarios aiming for different RES targets

To present a set of scenarios quantified by the PRIMES energy systems model 
Table 1. Cont.

\begin{tabular}{|c|c|c|}
\hline Author & Methods and Main Indicators & Aims \\
\hline $\begin{array}{l}\text { Cîrstea, Moldovan-Teselios, } \\
\text { Cîrstea, Turcu, and Darab } \\
\text { (2018) [11] }\end{array}$ & $\begin{array}{l}\text { Index construction based on } \\
\text { weighting and aggregation } \\
\text { data: RE mix shares, indicators } \\
\text { from sustainability dimensions of } \\
\text { the energy system (environmental, } \\
\text { e.g., quality of the natural } \\
\text { environment, renewable energy } \\
\text { consumption; institutional, } \\
\text { e.g., transparency of policymaking; } \\
\text { GDP per capita; social, } \\
\text { e.g., availability of latest } \\
\text { technology, spending on R\&D; } \\
\text { economic, e.g., production of RE, } \\
\text { inflation rate). The index uses } \\
\text { other rankings scores. }\end{array}$ & $\begin{array}{l}\text { To design a composite index: RE } \\
\text { Sustainability Index and use it to } \\
\text { examine European countries }\end{array}$ \\
\hline $\begin{array}{c}\text { Holma, Leskinen, Myllyviita, } \\
\text { Manninen, Sokka, Sinkko, and } \\
\text { Pasanen (2018) [17] }\end{array}$ & $\begin{array}{c}\text { Qualitative expert } \\
\text { judgment methods } \\
\text { data: share of energy from RES }\end{array}$ & $\begin{array}{c}\text { To discuss expert assessment of } \\
\text { the impacts and risks of RE } \\
\text { production in Finland }\end{array}$ \\
\hline $\begin{array}{l}\text { Papież, Śmiech, and Frodyma } \\
\text { (2018) [15] }\end{array}$ & $\begin{array}{l}\text { LARS (least angle regression), PCA } \\
\text { data: the share of RES in RE mix; } \\
\text { indicators from } 4 \text { dimensions: } \\
\text { environmental, e.g., } \mathrm{CO}_{2} \\
\text { emissions per capita; security, } \\
\text { e.g., energy import; economic, } \\
\text { e.g., GDP per capita, energy } \\
\text { consumption per capita and per } \\
\text { GDP, cost of energy; political } \\
\text { (dummy variables) }\end{array}$ & $\begin{array}{l}\text { To identify factors which } \\
\text { determine energy policy in EU } \\
\text { countries on the basis on the share } \\
\text { of RES in the RE mix }\end{array}$ \\
\hline $\begin{array}{l}\text { Pietrapertosa, Khokhlov, Salvia, } \\
\text { and Cosmi (2018) [16] }\end{array}$ & $\begin{array}{l}\text { Preliminary (yes/no) analysis of } \\
\text { the existing initiatives } \\
\text { data: an overview of the national } \\
\text { adaptation policies: National } \\
\text { Adaptation Strategy and National } \\
\text { Action Plan }\end{array}$ & $\begin{array}{c}\text { To overview adaptation initiatives } \\
\text { undertaken in } 11 \text { south-east } \\
\text { European countries with reference } \\
\text { to the policies and measures } \\
\text { promoted by the EU National } \\
\text { Adaptation Strategy and National } \\
\text { Action plan }\end{array}$ \\
\hline $\begin{array}{c}\text { Radulescu, Fedajev, Sinisi, } \\
\text { Popescu, and Iacob (2018) [27] }\end{array}$ & $\begin{array}{c}\text { Co-integration tests and OLS } \\
\text { panel regression } \\
\text { data: Selected Europe } 2020 \\
\text { strategy ratios, e.g., GDP, R\&D } \\
\text { expenses, employment rate, } \\
\text { energy consumption, GHG } \\
\text { emission etc. }\end{array}$ & $\begin{array}{l}\text { To determine the most important } \\
\text { ratios in the "Europe } 2020 \\
\text { Strategy" for sustainable and } \\
\text { inclusive growth }\end{array}$ \\
\hline $\begin{array}{l}\text { Soava, Mehedintu, Sterpu, and } \\
\text { Raduteanu (2018) [28] }\end{array}$ & $\begin{array}{l}\text { Linear regression models, panel } \\
\text { data techniques } \\
\text { data: GDP, energy consumption } \\
\text { from RES }\end{array}$ & $\begin{array}{c}\text { To examine the causal relationship } \\
\text { between economic growth and } \\
\text { RE consumption }\end{array}$ \\
\hline $\begin{array}{l}\text { Arbolino, Boffardi, and Ioppolo } \\
\text { (2019) [29] }\end{array}$ & $\begin{array}{c}\text { Hierarchical CA, convergence } \\
\text { analysis panel data model } \\
\text { (regression) } \\
\text { data: energy consumption shares } \\
\text { of energy consumption for } \\
\text { different RES and many variables } \\
\text { for CA defining levels of R\&D, } \\
\text { human capital, and } \\
\text { demographic features }\end{array}$ & $\begin{array}{l}\text { To propose an approach for } \\
\text { ex-post monitoring of the actions } \\
\text { implemented in Italian regions }\end{array}$ \\
\hline $\begin{array}{l}\text { Bórawski, Bełdycka-Bórawska, } \\
\text { Szymańska, Jankowski, Dubis, } \\
\text { and Dunn (2019) [30] }\end{array}$ & $\begin{array}{l}\text { Descriptive statistic and CA } \\
\text { data: share of RE in heating } \\
\text { cooling and transport }\end{array}$ & $\begin{array}{l}\text { To assess RE market development } \\
\text { with regard to biofuels in the EU }\end{array}$ \\
\hline
\end{tabular}


Table 1. Cont.

\begin{tabular}{|c|c|c|}
\hline Author & Methods and Main Indicators & Aims \\
\hline $\begin{array}{l}\text { Brożyna, Mentel, Ivanová, and } \\
\text { Sorokin (2019) [31] }\end{array}$ & $\begin{array}{c}\text { Hierarchical CA } \\
\text { data: indicators of RE }\end{array}$ & $\begin{array}{l}\text { To distinguish countries among } \\
\text { the new EU MSs that increased } \\
\text { their electrical capacity from RES }\end{array}$ \\
\hline $\begin{array}{l}\text { Cirstea, Tiron-Tudor, Nistor, } \\
\text { Cirstea, and Fulop (2019) [32] }\end{array}$ & $\begin{array}{l}\text { Multidimensional scaling data } \\
\text { reduction method and CA } \\
\text { data: energy indicators, } \\
\text { e.g., energy imports, energy use, } \\
\text { energy production, capacity, the } \\
\text { share of RES, GHG }\end{array}$ & $\begin{array}{l}\text { To measure the differences } \\
\text { between the countries in the } \\
\text { Eastern European region in terms } \\
\text { of RE and economic development }\end{array}$ \\
\hline Lindberg and Markard (2019) [6] & $\begin{array}{l}\text { Transition pathway (semi-coherent } \\
\text { pattern of major changes) analysis } \\
\text { data: list of key EU electricity } \\
\text { policies and their key } \\
\text { industry actors }\end{array}$ & $\begin{array}{c}\text { To assess the EU electricity policy } \\
\text { mix supporting different } \\
\text { transition pathways }\end{array}$ \\
\hline $\begin{array}{l}\text { Lyeonov, Pimonenko, Bilan, } \\
\text { Štreimikienè, and Mentel } \\
\text { (2019) [33] }\end{array}$ & $\begin{array}{c}\text { Modified OLS } \\
\text { data: GDP per capita and GHG } \\
\text { emissions, RE consumption, green } \\
\text { investment }\end{array}$ & $\begin{array}{l}\text { To analyze the linkages between } \\
\text { GDP per capita, GHG and RE in } \\
\text { the total final energy consumption } \\
\text { and green investments in the EU }\end{array}$ \\
\hline $\begin{array}{l}\text { Malinauskaite, Jouhara, Ahmad, } \\
\text { Milani, Montorsi, and Venturelli } \\
\text { (2019) [5] }\end{array}$ & $\begin{array}{c}\text { Descriptive statistics analysis } \\
\text { data: energy consumption trends, } \\
\text { sources and sectors, } \\
\text { energy savings }\end{array}$ & $\begin{array}{l}\text { To review EU strategies and } \\
\text { policies on energy efficiency; to } \\
\text { present national case studies for } \\
\text { Italy and the UK }\end{array}$ \\
\hline $\begin{array}{c}\text { Mikalauskiene, Štreimikis, } \\
\text { Mikalauskas, Stankūniene, and } \\
\text { Dapkus (2019) [34] }\end{array}$ & $\begin{array}{l}\text { Descriptive statistics analysis } \\
\text { data: GHG emissions and } \\
\text { removals by sector, a set of } \\
\text { indicators for the assessment of } \\
\text { energy intensity, the structure of } \\
\text { consumption, dependency, shares } \\
\text { of RES in sectors } \\
\text { Promethee II } \\
\text { data: } 12 \text { indicators from } 4\end{array}$ & $\begin{array}{l}\text { To assess GHG emission trends } \\
\text { and climate change mitigation } \\
\text { policies in the fuel combustion } \\
\text { sector of Lithuania and Bulgaria }\end{array}$ \\
\hline $\begin{array}{c}\text { Neofytou, Karakosta, and Gómez } \\
\text { (2019) [18] }\end{array}$ & $\begin{array}{l}\text { dimension: environmental } \\
\text { impacts, e.g., GHG reduction, } \\
\text { energy-saving; social impact, } \\
\text { e.g., employment; economic } \\
\text { impacts, e.g., GDP; energy systems } \\
\text { impacts, e.g., import, intensity }\end{array}$ & $\begin{array}{l}\text { To assess alternative climate and } \\
\text { energy policy scenarios and their } \\
\text { socioeconomic, environmental, } \\
\text { and energy impacts }\end{array}$ \\
\hline $\begin{array}{l}\text { Pach-Gurgul and Ulbrych } \\
\text { (2019) [35] }\end{array}$ & $\begin{array}{l}\text { Hellwig's multidimensional } \\
\text { comparative analysis } \\
\text { data: energy consumption, the } \\
\text { share of RE in energy consumption } \\
\text { MCDM, TOPSIS }\end{array}$ & $\begin{array}{l}\text { To empirically verify progress } \\
\text { made implementing the } \\
\text { provisions of the EU Energy } \\
\text { Package by the V4 countries }\end{array}$ \\
\hline $\begin{array}{l}\text { Siksnelyte and Zavadskas } \\
\text { (2019) [4] }\end{array}$ & $\begin{array}{l}\text { data: indicators for monitoring the } \\
\text { progress (electricity } \\
\text { interconnection, market } \\
\text { concentration, electricity prices, } \\
\text { retail electricity markets share of } \\
\text { RES in final electricity } \\
\text { consumption), indicators for the } \\
\text { assessment of sustainability: } \\
\text { economic (e.g., prices), } \\
\text { environmental (e.g., share of RES, } \\
\text { distribution losses) } \\
\text { security (import) }\end{array}$ & $\begin{array}{l}\text { To monitor the progress of the } \\
\text { electricity sector toward EU } \\
\text { objectives; assess the } \\
\text { sector sustainability }\end{array}$ \\
\hline
\end{tabular}


Table 1. Cont.

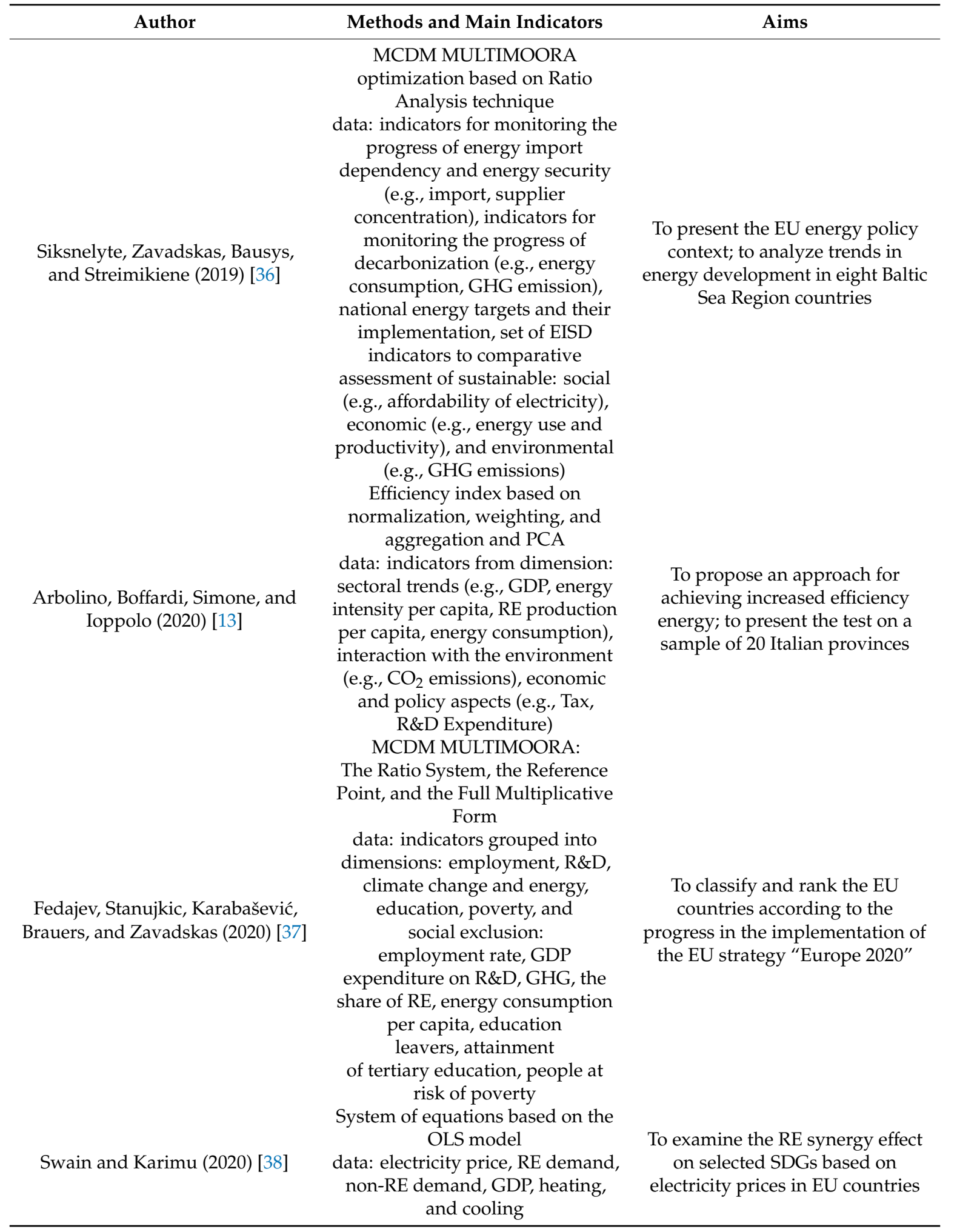

Abbreviations: AHP-analytical hierarchy process; CA—cluster analysis; EISD—Energy Indicators for Sustainable Development; ETS-emissions trading system; EU-European Union; GDP-gross domestic product; GHG—greenhouse gas; MAUT—multi-attribute utility theory; MCDM—-multi-objective decision-making, multi-criteria decision-making; MCM-multi-criteria method; MS - member state; OLS —ordinary least square; PCA—principal component analysis; R\&D—research and development; RE—renewable electricity, renewable energy; RES—renewable energy sources; SDG—sustainable development goals; SMART—simple multi-attribute ranking technique. 
Calculations and analyses were based on various indicators. Among the most commonly used were renewable energy shares/amount as indicators of energy sustainability $[4,5,11-13,15,17-20,22,23,25-35,37,38]$ and the associated greenhouse gas emission $[13,15,18,19,21,22,24,26,27,32-34,36,37]$.

Monitoring, rankings, and ratings of sustainability were made using various methods:

- qualitative descriptions or expert knowledge analysis [6,16-18];

- descriptive statistics analysis $[5,20,34]$;

- utilization of equations describing relations [22];

- $\quad$ scenario simulations $[19,21,26]$;

- $\quad$ aggregation of data to the index [11-13,35];

- $\quad$ regression models $[15,27,28,33,38]$;

- cluster analysis and principal component analysis methods [13,15,23,29-32];

- multidimensional statistical analysis [4,24,25,35-37].

The regression models could be divided into simple equations $[28,33,38]$ and extended, multiple variables $[15,27]$. Some authors created rankings based on several indicators [12] or their set that described different dimensions $[4,11,13,36,37]$. Policy and strategy studies were mostly a yes/no analysis of documents [16] or dependencies between them [6]. The portfolio of methods is extensive and still open for suggestions.

The main advantage of the DEA method is a comparative analysis of multiple variables. The method was applied empirically in many areas [39]. DEA-based assessment of sustainable development goals allows for the relativization of performance based on the underlying relationship between the weighted sum of results and the weighted sum of cost [40]. The issues of weighting are solved using objective linear programming. Table 2 presents examples of DEA applications for the assessment of sustainability in EU countries. In this case, the inputs and outputs are given as a reference to previous studies and practice.

Table 2. Example of papers relevant to Data Envelopment Analysis (DEA) and EU sustainability.

\begin{tabular}{|c|c|c|c|}
\hline Authors & DEA Models & Aims & Variables \\
\hline $\begin{array}{l}\text { Grochová and Myšková } \\
\text { (2016) [41] }\end{array}$ & $\begin{array}{l}\text { Standard DEA BCC } \\
\text { model with slacks }\end{array}$ & $\begin{array}{l}\text { To assess the ability of } \\
\text { EU countries to achieve } \\
\text { the objectives of } \\
\text { Strategy } 2020\end{array}$ & $\begin{array}{l}\text { Input: electricity production from } \\
\text { RES, alternative and nuclear } \\
\text { energy, fossil fuel energy, adjusted } \\
\text { savings of } \mathrm{CO}_{2} \text { damage } \\
\text { Output: unemployment, GDP } \\
\text { per capita }\end{array}$ \\
\hline $\begin{array}{l}\text { Iftikhar, He, and Wang } \\
\text { (2016) [42] }\end{array}$ & $\begin{array}{l}\text { SBM DEA model with an } \\
\text { undesirable output }\end{array}$ & $\begin{array}{l}\text { To analyze energy and } \\
\mathrm{CO}_{2} \text { emission efficiency } \\
\text { (ECEE) of major } \\
\text { economies (including } \\
\text { the EU) }\end{array}$ & $\begin{array}{l}\text { Input: labor, capital, energy } \\
\text { Output: GDP } \\
\text { Undesirable output: } \mathrm{CO}_{2}\end{array}$ \\
\hline $\begin{array}{l}\text { Madaleno Moutinho, } \\
\text { and Robaina (2016) [43] }\end{array}$ & $\begin{array}{c}\text { Standard CCR and BCC } \\
\text { DEA models }\end{array}$ & $\begin{array}{l}\text { To estimate and compare } \\
\text { the efficiency }\end{array}$ & $\begin{array}{c}\text { Input: capital, labor, fossil fuel, RE } \\
\text { or GDP per labor, GDP per capita, } \\
\text { fossil fuel per GDP } \\
\text { Output: GDP per GHG }\end{array}$ \\
\hline $\begin{array}{l}\text { Sanz, Yñiguez, and } \\
\text { Velasco (2016) [44] }\end{array}$ & $\begin{array}{l}\text { DEA with a desirable } \\
\text { and undesirable output } \\
\text { and MI }\end{array}$ & $\begin{array}{l}\text { To analyze the efficiency } \\
\text { of EU countries, focusing } \\
\text { on Spain }\end{array}$ & $\begin{array}{c}\text { Input: gross capital formation } \\
\text { (GCF), energy consumption, RE } \\
\text { consumption, } \\
\text { Output: GDP } \\
\text { Undesirable output: GHG }\end{array}$ \\
\hline
\end{tabular}


Table 2. Cont.

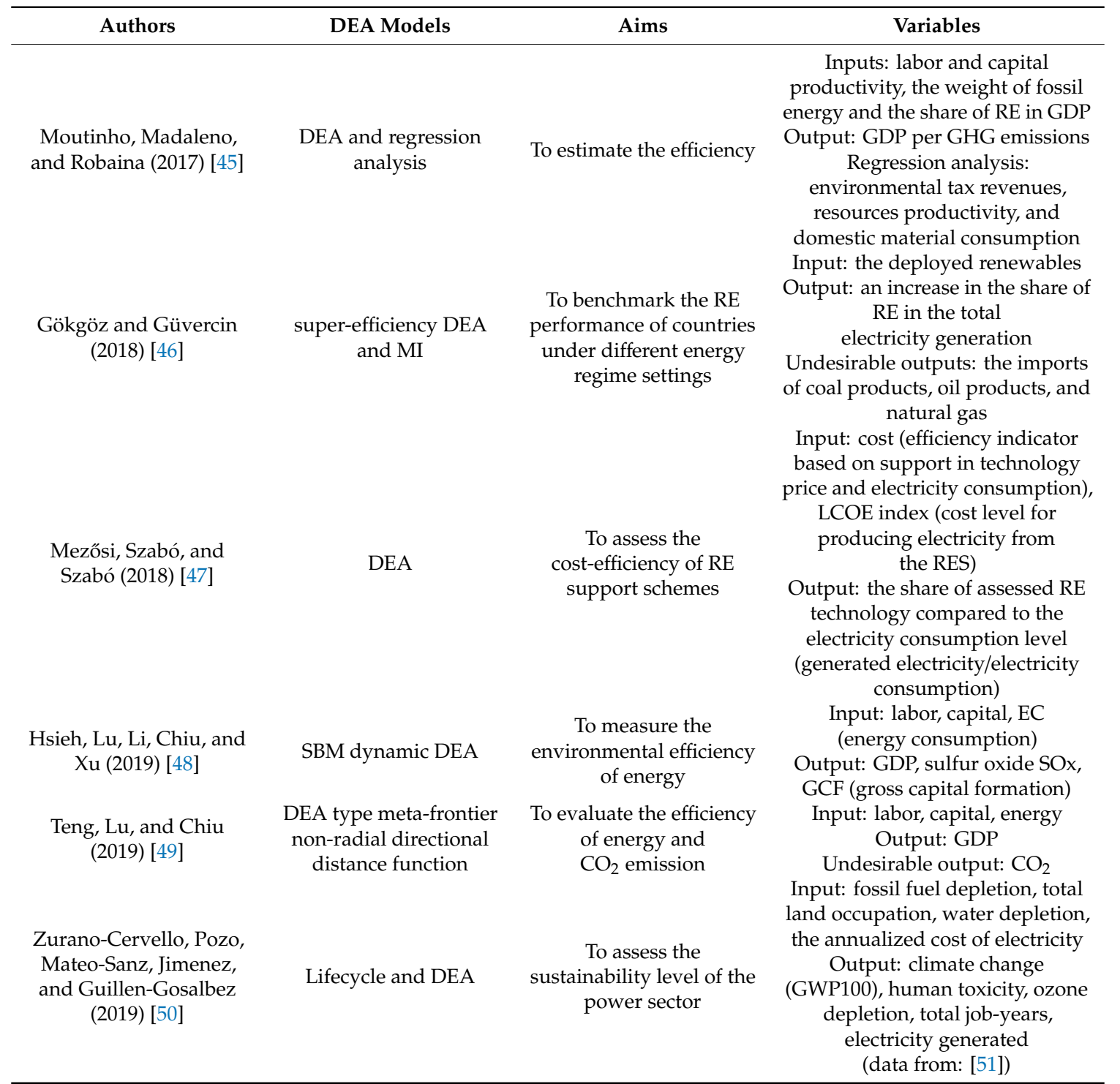

Abbreviations: BCC—introduced by Banker, Charnes and Cooper [52] DEA model; CCR-Charnes, Cooper and Rhodes [53] basic DEA model; DEA—Data Envelopment Analysis; MI—Malmquist index; SBM—slacks-based measure; EU—European Union; GDP—gross domestic product; GHG—greenhouse gas; RE—renewable electricity, renewable energy; RES—renewable energy sources.

Hence, DEA-based approaches to the assessment of sustainability in different countries were used for various purposes. In some instances, the focus was placed on efficiency while transforming hard data on labor, capital, and energy into GDP. Other papers considered the associated production of pollutants (mainly greenhouse gas emissions) [45,48,49] and renewables [45-47]. Changing trends of RE amounts $[46,48,49]$ was another popular area of assessment.

Papers in Tables 1 and 2 provide references that are mainly notes and documents published by EU institutions, primarily the European Commission (EC). The popular references were: A policy framework for climate and energy in the period from 2020 to 2030 [54] in [12,16,18,20,22,36]; Energy Roadmap 2050 [55] in [4,5,16,18,21,22,26,36]; and EU Energy 2020-A Strategy for Competitive, Sustainable and Secure Energy [56] in [4,12,20,22,36]. Just as frequent were Clean Energy for All Europeans-unlocking Europe's growth potential [57] in [4,5,26,30,36], Guidelines on State aid for environmental protection and energy, 2014-2020 [58] in [6,47]; Climate Action-Paris Agreement [59] in [44]; and 2030 Climate and Energy Goals for a Competitive, Secure and Low-carbon EU Economy [60] in [25]. In some instances, 
references were made to a set of documents related to energy, e.g., Energy Strategy and Energy Union [61] in [32]. Some documents were issued by the Council of the European Union, e.g., EU Response to the 2030 Agenda for Sustainable Development a Sustainable European [62] in [30]. The United Nations (UN) outlines in Sustainable development goals [3,63] were the most popular reference in documents issued by international agencies, cited in $[4,11,24,32,33,38]$. Another important reference was reports of the International Atomic Energy Agency (IAEA), such as Energy Indicators for Sustainable Development: Guidelines and Methodologies [64], used in [4,11-13,34,36].

To sum up, data was mainly taken from the EU statistical office Eurostat [65] in $[4,15,19,20,22,23,28,30-38,41,43,44]$ or the European Environmental Agency (EEA) [66] in $[5,18,23,29,30,33,38,43,50]$. Also, EU documents and websites were used, such as EC Europe 2020 Targets: Statistics and Indicators at the EU Level [67] in [27]. The indicated reliable data and reports were also provided by the International Energy Agency [10] in [1,4,11,13,21-23,28,29,34-36,38,46,48,50]. Other popular data sources were the World Bank Open Data [68] mentioned in [12,32,33,41,42,46], World Energy Council [69] cited in [12,13,23] or the estimation of the European Investment Bank [70] in [22]. In the case of individual country analysis, the local data sources were used, e.g., the Italian National Institute of Statistic, the Italian company GSE [13,29] or the Latvian Ministry of Environmental and Regional Development [24]. The data sources were also reports of independent research and consulting firms, such as Enerdata, Global Energy Statistical Yearbook [71] in [42]. This article used the International Energy Agency (IEA) data [72] and the soft data on social authorization for moving toward a low-carbon economy from an EC survey Europeans' attitudes on energy policy [73].

The cited papers assumed that the data underlying the assumption were solid and reliable. Most of them analyzed absolute energy sustainability indicators from statistical databases. The few cases that used qualitative data treated it in the same way: the transformation into numerical variables was a conversion to zero-one values [15,16]. Also, it was used directly as expert opinions [17,18]. Conversion of qualitative data into quantitative data without considering the subjectivity and the resulting uncertainty was associated with the loss of information, shallow conclusions, and misinterpretation.

There are many approaches to incorporation of uncertainty into the DEA, e.g., chance-constrained DEA model [74]. In the context of sustainability assessment, uncertainty in data is mainly modeled using concepts derived from Fuzzy Sets [75,76]. For example, DEA and fuzzy best and worst methods were combined and used to prioritize renewable energy sources [77]. Fuzzy numbers were used to describe the ambiguity of a qualitative index used to assess an RE technical plan [78]. This article proposes a hybrid model that integrates the Rough Set theory and DEA to model the vagueness of data. Rough Sets, although different with some origin assumptions, by some authors are treated as an approach derived from Fuzzy Sets $[79,80]$. The merging of concepts from the set theory and operational research address the need for multifaceted and objective assessment as it proved to be effective in the case of technology prioritization [81]. Fuzzy sets in non-empty space are based on the membership function. Using the membership function relates to the basic problem of choosing the method of its construction. The Rough Set theory, which does not require special assumptions as to data and probability distribution, characterized by mathematical simplicity, has found many applications. However, the combination of Rough Sets with the DEA method is unpopular and relatively rarely used.

\section{Methods}

Data Envelopment Analysis (DEA) is a linear programming technique that allows evaluating the relative efficiency of Decision-Making Units (DMUs). The method was initiated by Charnes, Cooper, and Rhodes (1978) [53] based on a paper by Farrell (1957) [82] and his concept of the best practice frontier. The DEA method uses the idea of technical efficiency. It evaluates the performances of the units, considering the relationship of outputs and inputs in connection to the value of this relationship in other DMUs covered by the study (Figure 1). 


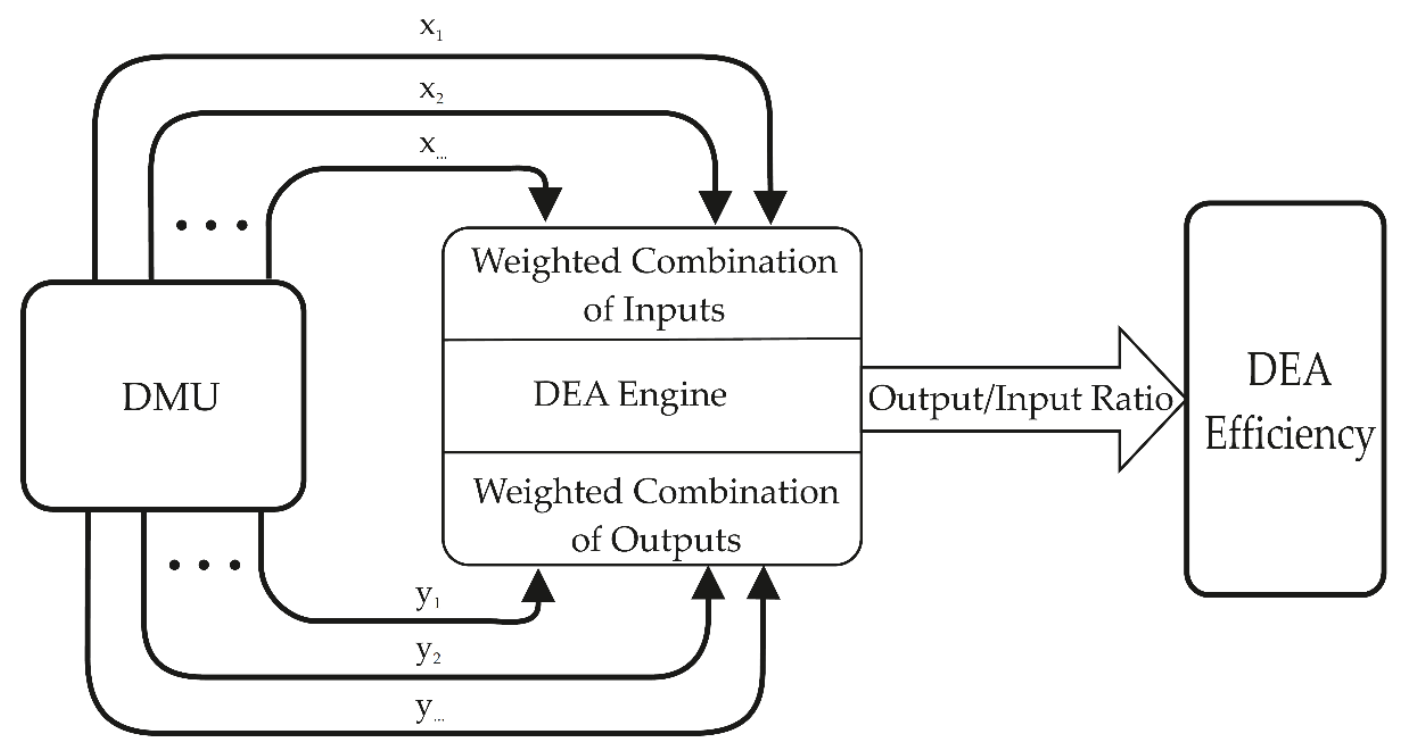

Figure 1. DEA concept.

Considering $n$ DMUs where each $\mathrm{DMU}_{j}, j \in J=\{1, \ldots, n\}$ uses $m$ inputs $x_{j}=\left(x_{1 j}, x_{2 j}, \ldots, x_{i j}, \ldots, x_{m j}\right), i \in I=\{1, \ldots, m\}$, and produces $s$ outputs $y_{j}=\left(y_{1 j}, y_{2 j}, \ldots, y_{r j}, \ldots, y_{s j}\right)$, $r \in O=\{1, \ldots, s\}$, the standard BCC-O DEA model (the output oriented Banker, Charnes, and Cooper model [52], applicable to technologies characterized by variable returns to scale) can be written as follows:

$$
\begin{gathered}
\max \phi, \\
\sum_{j=1}^{n} \lambda_{j} x_{i j} \leq x_{i j_{O}}, i=1, \ldots, m, \\
\sum_{j=1}^{n} \lambda_{j} y_{r j} \geq \phi y_{r j_{O}}, r=1, \ldots, s, \\
\sum_{j=1}^{n} \lambda_{j}=1, \lambda_{j} \geq 0 .
\end{gathered}
$$

The score $\phi$, specified in Equation (1) ranges from 0 for the worst performing units, to $100 \%$, for the best ones. The symbol $\lambda_{j}$ represents the weight of DMU $j$.

In the case of sustainability assessment and comparisons, data $\left(x_{j}, y_{j}\right)$ are often presented and interpreted in the form of ratios rather than in absolute numbers (e.g., GDP per capita, or $\mathrm{CO}_{2}$ per GDP). On the other hand, subjects of decision are numerators $\left(\bar{x}_{j}, \bar{y}_{j}\right)$ and denominators $\left(\underline{x}_{j}, \underline{y}_{j}\right)$ of these fractions $\left(x_{j}, y_{j}\right)$. The basic standard CCR model (Charnes, Cooper, and Rhodes [20] DEA model) is technically incorrect when data is used in the form of ratios [83-86]. Assuming $I^{R} \subseteq I$ and $O^{R} \subseteq O$ represent, respectively, ratio inputs and ratio outputs, and $I^{A}=I \backslash I^{R}$ and $O^{A}=O \backslash O^{R}$ represent absolute (non-relative) inputs and outputs and, furthermore, $x_{i j}=\frac{\bar{x}_{i j}}{\underline{x}_{i j}}$, for each $i \in I^{R}$ and $y_{r j}=\frac{\bar{y}_{r j}}{\underline{y}_{r j}}$, for each $r \in O^{R}$, the BCC model Equation (1) can be deployed [83] or the nonlinear solution $[84,85]$ Equation (2):

$$
\begin{gathered}
\max \phi, \\
\sum_{j=1}^{n} \lambda_{j} x_{i j} \leq x_{i j_{O}}, i \in I^{A}, \\
\sum_{j=1}^{n} \lambda_{j} y_{r j} \geq \phi y_{r j_{j}}, r \in O^{A}, \\
\sum_{j=1}^{n} \lambda_{j}\left(\bar{x}_{i j}-x_{i j_{O}} \underline{x}_{i j}\right) \leq 0, i \in I^{R}, \\
\sum_{j=1}^{n} \lambda_{j} \bar{y}_{r j}-\phi y_{r j_{O}} \sum_{j=1}^{n} \lambda_{j} \underline{y}_{r j} \geq 0, r \in O^{R}, \\
\sum_{j=1}^{n} \lambda_{j}=1, \lambda_{j} \geq 0 .
\end{gathered}
$$

Symbols used as in Equation (1). 
This paper proposes to integrate DEA and Rough Set methods to deal with data uncertainty [87]. The Rough Set theory, introduced by Pawlak (1982) [88], is a mathematical approach to vagueness and uncertainty. The uncertainty modelling with the concept of rough variables of inputs and outputs [89]: $\left[x_{i j}^{a}, x_{i j}^{b}\right],\left[x_{i j}^{c}, x_{i j}^{d}\right],\left[y_{r j}^{a}, y_{r j}^{b}\right],\left[y_{r j}^{c}, y_{r j}^{d}\right]$, where: $x_{i j}^{c} \leq x_{i j}^{a}<x_{i j}^{b} \leq x_{i j}^{d}, y_{r j}^{c} \leq y_{r j}^{a}<y_{r j}^{b} \leq y_{r j}^{d}, i=1, \ldots, m$, and $r=1, \ldots, s$ is presented in Figure 2. The ranges $\left[x_{i j}^{a}, x_{i j}^{b}\right]$ and $\left[y_{r j}^{a}, y_{r j}^{b}\right]$ represent lower approximations, $\left[x_{i j}^{c}, x_{i j}^{d}\right]$ and $\left[y_{r j}^{c}, y_{r j}^{d}\right]$ upper approximations (boundaries) of the unknown real values of input $x_{i j}$ and output $y_{r j}$, respectively.

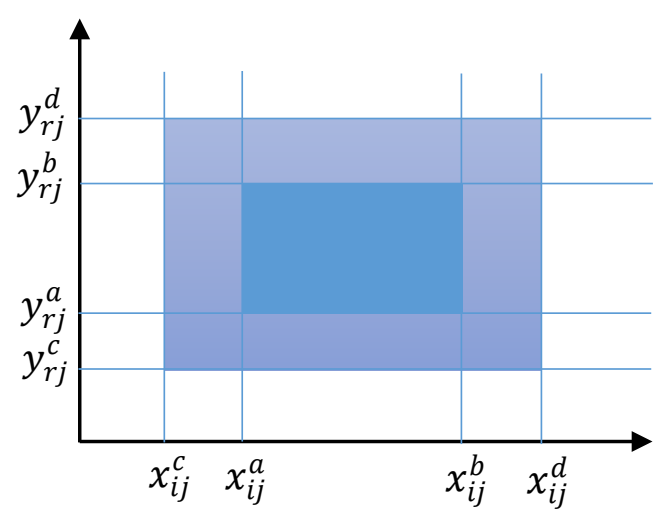

Figure 2. Concept of rough input-output variables.

Using the concept of trust in rough variables and assuming the level $\alpha$, such as $0.5 \leq \alpha \leq 1$, $\alpha$-optimistic and $\alpha$-pessimistic values can be calculated for each rough variable and each DMU: $\left[x_{i j}^{\inf (\alpha)}, x_{i j}^{\sup (\alpha)}\right],\left[y_{r j}^{\inf (\alpha)}, y_{r j}^{\sup (\alpha)}\right]$ [89]. The following Equations (3)-(6) formulas can be used:

$$
\begin{aligned}
& x_{i j}^{\sup (\alpha)}= \begin{cases}(1-2 \alpha) x_{i j}^{d}+2 \alpha x_{i j}^{c}, & \text { if } 0 \leq \alpha \leq \frac{x_{i j}^{d}-x_{i j}^{b}}{2\left(x_{i j}^{d}-x_{i j}^{c}\right)} \\
2(1-\alpha) x_{i j}^{d}+(2 \alpha-1) x_{i j}^{c}, & \text { if } \frac{2 d-x_{i j}^{a}-x_{i j}^{c}}{2\left(x_{i j}^{d}-x_{i j}^{c}\right)} \leq \alpha \leq 1, \\
\frac{x_{i j}^{d}\left(x_{i j}^{b}-x_{i j}^{a}\right)+x_{i j}^{b}\left(x_{i j}^{d}-x_{i j}^{c}\right)-2 \alpha\left(x_{i j}^{b}-x_{i j}^{a}\right)\left(x_{i j}^{d}-x_{i j}^{c}\right)}{\left(x_{i j}^{b}-x_{i j}^{a}\right)+\left(x_{i j}^{d}-x_{i j}^{c}\right)}, & \text { otherwise }\end{cases} \\
& x_{i j}^{i n f(\alpha)}= \begin{cases}(1-2 \alpha) x_{i j}^{c}+2 \alpha x_{i j^{\prime}}^{d} & \text { if } 0 \leq \alpha \leq \frac{x_{i j}^{a}-x_{i j}^{c}}{2\left(x_{i j}^{d}-x_{i j}^{c}\right)} \\
2(1-\alpha) x_{i j}^{c}+(2 \alpha-1) x_{i j}^{d}, & \text { if } \frac{x_{i j}^{b}+x_{i j}^{d}-2 x_{m j}^{c}}{2\left(x_{i j}^{d}-x_{i j}^{c}\right)} \leq \alpha \leq 1, \\
\frac{x_{i j}^{c}\left(x_{i j}^{b}-x_{i j}^{a}\right)+x_{i j}^{a}\left(x_{i j}^{d}-x_{i j}^{c}\right)-2 \alpha\left(x_{i j}^{b}-x_{i j}^{a}\right)\left(x_{i j}^{d}-x_{i j}^{c}\right)}{\left(x_{i j}^{b}-x_{i j}^{a}\right)+\left(x_{i j}^{d}-x_{i j}^{c}\right)}, & \text { otherwise }\end{cases} \\
& y_{r j}^{\sup (\alpha)}= \begin{cases}(1-2 \alpha) y_{r j}^{d}+2 \alpha y_{r j}^{c}, & \text { if } 0 \leq \alpha \leq \frac{y_{r j}^{d}-y_{r j}^{b}}{2\left(y_{r j}^{d}-y_{r j}^{c}\right)} \\
2(1-\alpha) y_{r j}^{d}+(2 \alpha-1) y_{r j}^{c}, & \text { if } \frac{2 y_{r j}^{d}-y_{r j}^{a}-y_{r j}^{c}}{2\left(y_{r j}^{d}-y_{r j}^{c}\right)} \leq \alpha \leq 1, \\
\frac{d\left(b-y_{r j}^{a}\right)+y_{r j}^{b}\left(y_{r j}^{d}-y_{r j}^{c}\right)-2 \alpha\left(y_{r j}^{b}-y_{r j}^{a}\right)\left(y_{r j}^{d}-y_{r j}^{c}\right)}{\left(y_{r j}^{b}-y_{r j}^{a}\right)+\left(y_{r j}^{d}-y_{r j}^{c}\right)}, & \text { otherwise }\end{cases}
\end{aligned}
$$




$$
y_{r j}^{\inf (\alpha)}= \begin{cases}(1-2 \alpha) y_{r j}^{c}+2 \alpha y_{r j}^{d}, & \text { if } 0 \leq \alpha \leq \frac{y_{r j}^{a}-y_{r j}^{c}}{2\left(y_{r j}^{d}-y_{r j}^{c}\right)} \\ 2(1-\alpha) y_{r j}^{c}+(2 \alpha-1) y_{r j}^{d}, & \text { if } \frac{y_{r j}^{b}+y_{r j}^{d}-2 y_{r j}^{c}}{2\left(y_{r j}^{d}-y_{r j}^{c}\right)} \leq \alpha \leq 1, \\ \frac{y_{r j}^{c}\left(y_{r j}^{b}-y_{r j}^{a}\right)+y_{r j}^{a}\left(y_{r j}^{d}-y_{r j}^{c}\right)-2 \alpha\left(y_{r j}^{b}-y_{r j}^{a}\right)\left(y_{r j}^{d}-y_{r j}^{c}\right)}{\left(y_{r j}^{b}-y_{r j}^{a}\right)+\left(y_{r j}^{d}-y_{r j}^{c}\right)}, & \text { otherwise }\end{cases}
$$

The Rough Set DEA model results in the range of efficiency indicators for the assumed level of $\alpha$ : $\left[\phi^{\inf (\alpha)}, \phi^{\sup (\alpha)}\right][81,89]$ :

$$
\begin{aligned}
& \max \phi^{\sup (\alpha)} \\
& \sum_{j=1, j \neq j_{O}}^{n} \lambda_{j} x_{i j}^{\text {sup }(\alpha)}+\lambda_{j_{O}} x_{i j_{O}}^{\inf (\alpha)} \leq x_{i j_{O}}^{\inf (\alpha)}, i=1, \ldots, m, \\
& \sum_{j=1, j \neq j_{O}}^{n} \lambda_{j} y_{r j}^{\inf (\alpha)}+\lambda_{j o} y_{r j_{O}}^{\text {sup }(\alpha)} \geq \phi^{\sup (\alpha)} y_{r j_{O}}^{\sup (\alpha)}, r=1, \ldots, s, \\
& \sum_{j=1}^{n} \lambda_{j}=1, \lambda_{j} \geq 0, j=1, \ldots n \text {; } \\
& \begin{array}{c}
\max \phi^{\inf (\alpha)}, \\
\sum_{j=1, j \neq j_{O}}^{n} \lambda_{j} x_{i j}^{\inf (\alpha)}+\lambda_{j_{0}} x_{i j_{O}}^{\sup (\alpha)} \leq x_{i j_{O}}^{\sup (\alpha)}, i=1, \ldots, s,
\end{array} \\
& \sum_{j=1, j \neq j_{O}}^{n} \lambda_{j} y_{r j}^{\sup (\alpha)}+\lambda_{j_{O}} y_{r j_{O}}^{\inf (\alpha)} \geq \phi^{\text {inf }(\alpha)} y_{r j_{O}}^{\inf (\alpha)}, r=1, \ldots, s, \\
& \sum_{j=1}^{n} \lambda_{j}=1, \lambda_{j} \geq 0, j=1, \ldots n .
\end{aligned}
$$

Achievement of sustainability goals is the effect of many consecutive stages (subprocesses). Network DEA models are multistage. They allow examining the efficiency of DMUs that have internal network structures and provide measures for the components that make up the DMUs [90]. Presented below is a general two-stage process, where the first stage uses inputs $x_{j}=\left(x_{1 j}, x_{2 j}, \ldots, x_{i j}, \ldots, x_{m j}\right)$ $i \in I=\{1, \ldots, m\}$ to produce outputs $z_{j}=\left(z_{1 j}, z_{2 j}, \ldots, z_{d j}, \ldots, z_{D j}\right) d \in D=\{1, \ldots, D\}$, and then, these $z_{j}$ are used as inputs of the second stage to produce outputs $y_{j}=\left(y_{1 j}, y_{2 j}, \ldots, y_{r j}, \ldots, y_{s j}\right)$, $r \in O=\{1, \ldots, s\}$, where $\sim$ represents unknown decision variables. Assuming $w_{1}$ and $w_{2}$ are weights that are specified by users and reflect the user preference [91]:

$$
\begin{gathered}
\operatorname{minw}_{1} \phi_{1}-w_{2} \phi_{2}, \\
\sum_{j=1}^{n} \lambda_{j} x_{i j} \leq \phi_{1} x_{i j_{O}}, i=1, \ldots, m, \\
\sum_{j=1}^{n} \lambda_{j} z_{d j} \geq \widetilde{z}_{d j_{O}}, d=1, \ldots, D, \\
\sum_{j=1}^{n} \lambda_{j}=1, \lambda_{j} \geq 0, \\
\sum_{j=1}^{n} \mu_{j} z_{d j} \leq \widetilde{z}_{d j_{O}}, d=1, \ldots, D, \\
\sum_{j=1}^{n} \mu_{j} y_{r j} \geq \phi_{2} y_{r j_{O}}, r=1, \ldots, s, \\
\sum_{j=1}^{n} \mu_{j}=1, \mu_{j} \geq 0 .
\end{gathered}
$$

In the case of a rough variable, for example $z$ from the range: $\left[z_{d j^{\prime}}^{a} z_{d j}^{b}\right]$, where: $z_{d j}^{a}<z_{d j^{\prime}}^{b}$ $d \in D=\{1, \ldots, D\}$ formulas Equations (3)-(6) reduce to:

$$
\begin{aligned}
z_{d j}^{\text {inf }(\alpha)} & =\alpha z_{d j}^{a}+(1-\alpha) z_{d j^{\prime}}^{b} \\
z_{d j}^{\text {sup }(\alpha)} & =(1-\alpha) z_{d j}^{a}+\alpha z_{d j}^{b} .
\end{aligned}
$$

For $\alpha=0.5\left[z_{d j}^{\inf (\alpha)}, z_{d j}^{\sup (\alpha)}\right]$ reduces to mean: $\left[\left(z_{d j}^{a}+z_{d j}^{b}\right) / 2,\left(z_{d j}^{a}+z_{d j}^{b}\right) / 2\right]$, and for $\alpha=1.0$ to origin range: $\left[z_{d j}^{a}, z_{d j}^{b}\right]$.

The presented models and their combinations can be used to assess the level of development of EU countries from the perspective of sustainability. The main advantages of Rough DEA include 
the simple interpretation of both the level of trust: the higher the wider the efficiency range, and the relations: to obtain the maximum score the best characteristics of the evaluated DMU is compared with the worst of others and vice versa while forming the lower bounds.

\section{Results}

\subsection{Discussion of Data and Models}

In the literature the conventional data for productivity analysis by DEA are labor and capital as inputs and economic growth measured by GDP as an output. In the case of sustainability development assessment, the volume of energy is considered as the main input of GDP. It is used in the form of, e.g., the share of RE, resource depletion, and GHG emissions (Table 2).

Data on sustainable development are processed by many institutions, e.g., the World Bank, the European Environment Agency (EEA), and Eurostat. Differences in collection and aggregation methodologies often imply a certain inconsistency in the published data. In this study, hard data: GDP (in billion US dollars using 2010 exchange rates), population (in millions), and $\mathrm{CO}_{2}$ emissions (in millions of tons of $\mathrm{CO}_{2}$ ) in 2017 were taken from IEA (2019), $\mathrm{CO}_{2}$ Emissions from Fuel Combustion [72].

The soft data is based on the survey Europeans' Attitudes on Energy Policy [73], which was conducted in $28 \mathrm{EU}$ member states. The survey revealed a high consensus and positive attitude toward the current energy policy. For example, about $60 \%$ of respondents totally agreed, and $30 \%$ tended to agree with statements "it should be the EU's responsibility to encourage more investment in renewable energy" and "it should be the EU's responsibility to encourage more investment in energy research and innovation". The percentages of agreements were correlated between countries. The Pearson's correlation coefficient for the statements was 0.9 . The most frequent answer regarding the priorities for the next five years was investments in clean energy technology and their development. Respondents had less enthusiasm about the reduction of the impact made by energy on climate change and the reduction of the overall energy consumption in the EU.

The agreement to the statement that "it should be the EU's responsibility to encourage more investment in renewable energy" was chosen to reflect the social authorization and readiness for change. The following relationship was assumed: the socio-economic environment (the social agreement to investments and robust data on a country's standard of living measured by GDP per capita) influences $\mathrm{CO}_{2}$ emissions. A simple DEA model was used for total agreements only (Figure 3a), and Rough DEA — for total agreements and tendencies to agree, thus creating a rough variable (Figure $3 b$ ).

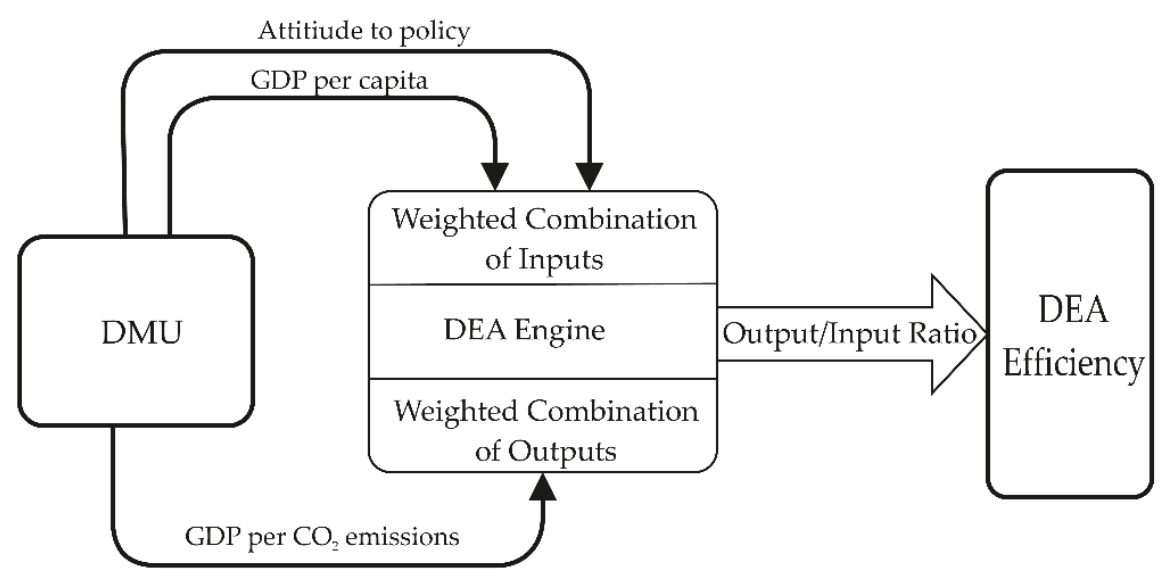

(a)

Figure 3. Cont. 


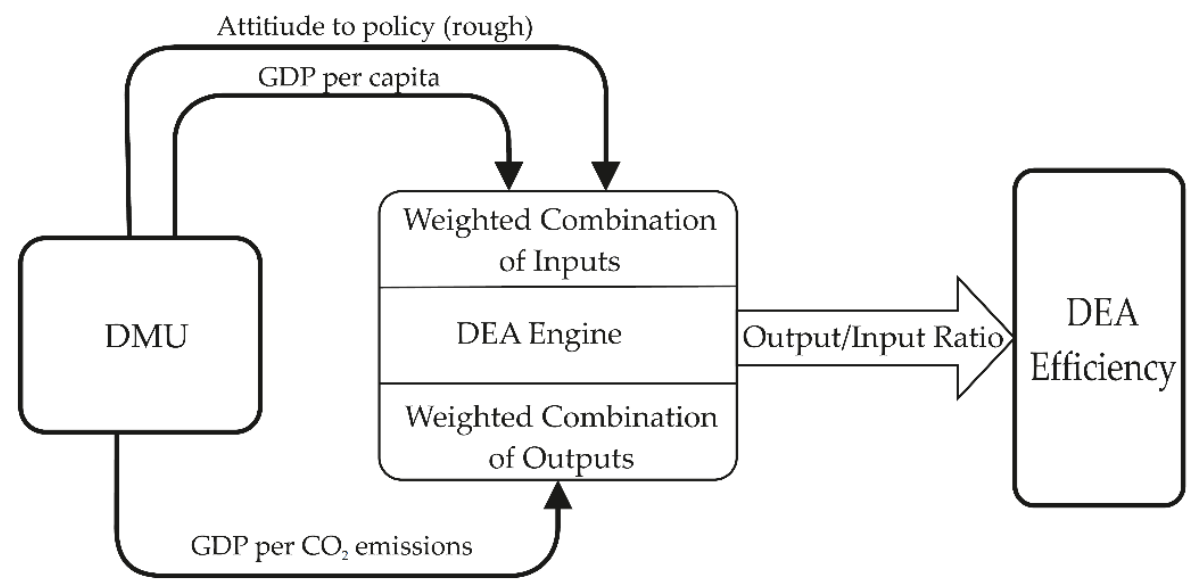

(b)

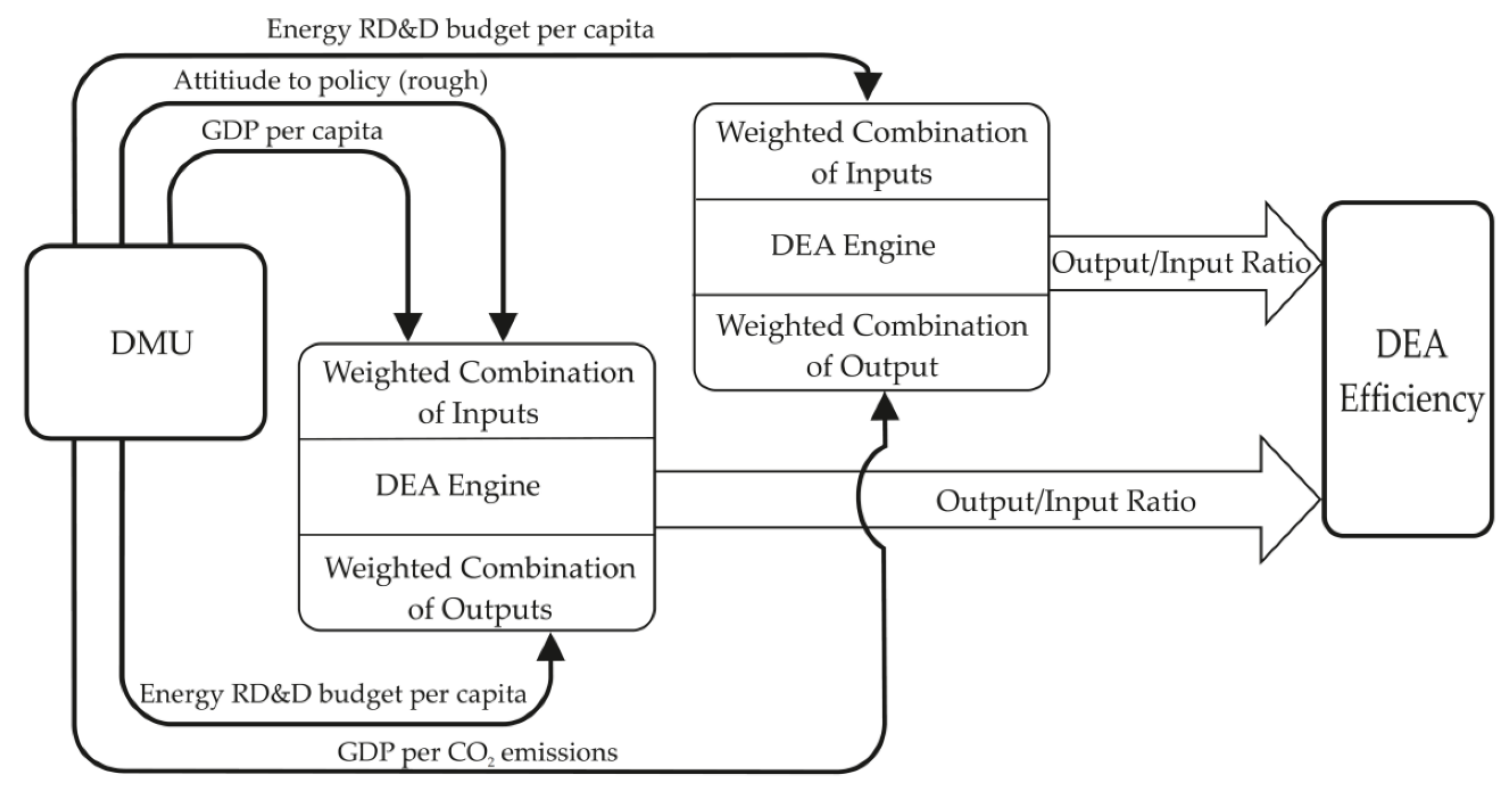

(c)

Figure 3. Tested model: (a) BCC DEA and Ratio DEA; (b) Rough DEA; (c) Rough network DEA.

The network Rough DEA model was also used to assess efficiencies of investments in low-carbon development. The authors analyzed the transformation of agreement with investments and the standard of living into the value of investments in energy (the first stage) and the value of investments in low-carbon development (the second stage) (Figure 3c).

Referring to the equations of the models presented in the Methods section, as $x_{1}$ was taken attitude to policy, as $x_{2}$ GDP per capita, as $y_{1}$ GDP per $\mathrm{CO}_{2}$ emission in DEA and Rough DEA model. In network Rough DEA model, $x_{1}$ represented attitude to policy, $x_{2}$ GDP per capita, $z j$ total public energy for research, development and deployment (RD\&D) budget, $y_{1}$ GDP per $\mathrm{CO}_{2}$ emission. Equal weights $w_{1}$ and $w_{2}$ was assumed, and $\alpha=0.6$, and $\alpha=0.8$.

The data on the total public budget (in millions US dollars) allocated for research, development and deployment (RD\&D) of energy technologies in 2017 was taken from IEA [10]. Not all data was available. For this reason, network Rough DEA analysis was performed on a smaller data set. Due to the limitation of the DEA model assuming a positive relationship between inputs and outputs, the degree of low-carbon economies was measured by the inverse of the classical $\mathrm{CO}_{2}$ value per GDP. The summaries of data covered by the analysis are presented in Tables $3-5$ and Figures 4 and 5 . 
Table 3. Descriptive statistics of data.

\begin{tabular}{ccccccc}
\hline & $\begin{array}{c}\text { GDP } \\
\text { [B US \$] }\end{array}$ & $\begin{array}{c}\text { Population } \\
{[\mathbf{M}]}\end{array}$ & $\begin{array}{c}\mathbf{C O}_{2} \\
\text { in [M T] }\end{array}$ & $\begin{array}{c}\text { Total Public Energy } \\
\text { RD\&D Budget [M US \$] }\end{array}$ & $\begin{array}{c}\text { EU Should Encourage } \\
\text { Investments in Energy [\%] } \\
\text { Totally } \\
\text { Agree }\end{array}$ & $\begin{array}{c}\text { Tend to and } \\
\text { Totally Agree }\end{array}$ \\
\hline $\begin{array}{c}\text { Avg. } \\
\text { Std. dev. }\end{array}$ & 672.39 & 18.30 & 114.62 & 310.80 & 61.18 & 91.18 \\
\hline
\end{tabular}

Abbreviations: RD\&D—research, development and deployment.

Table 4. Data correlations (absolute variables).

\begin{tabular}{ccc}
\hline & GDP & $\mathrm{CO}_{2}$ \\
\hline $\mathrm{CO}_{2}$ & 0.932 & \\
Population & 0.962 & 0.946 \\
\hline
\end{tabular}

Table 5. Data correlations (ratio variables).

\begin{tabular}{cccc}
\hline & GDP per Capita & GDP per $\mathrm{CO}_{2}$ & $\begin{array}{c}\text { EU Should Encourage Investments: } \\
\text { Totally Agree }\end{array}$ \\
\hline $\begin{array}{c}\text { GDP/CO } \\
\text { RD\&D budget per capita }\end{array}$ & 0.680 & & \\
EU should encourage investments: & 0.593 & 0.443 & \\
$\begin{array}{c}\text { totally agree } \\
\text { tend to agree and totally agree }\end{array}$ & $0.248^{1}$ & 0.433 & 0.646 \\
\hline
\end{tabular}

${ }^{1}$ Statistically insignificant with $p<0.05$.

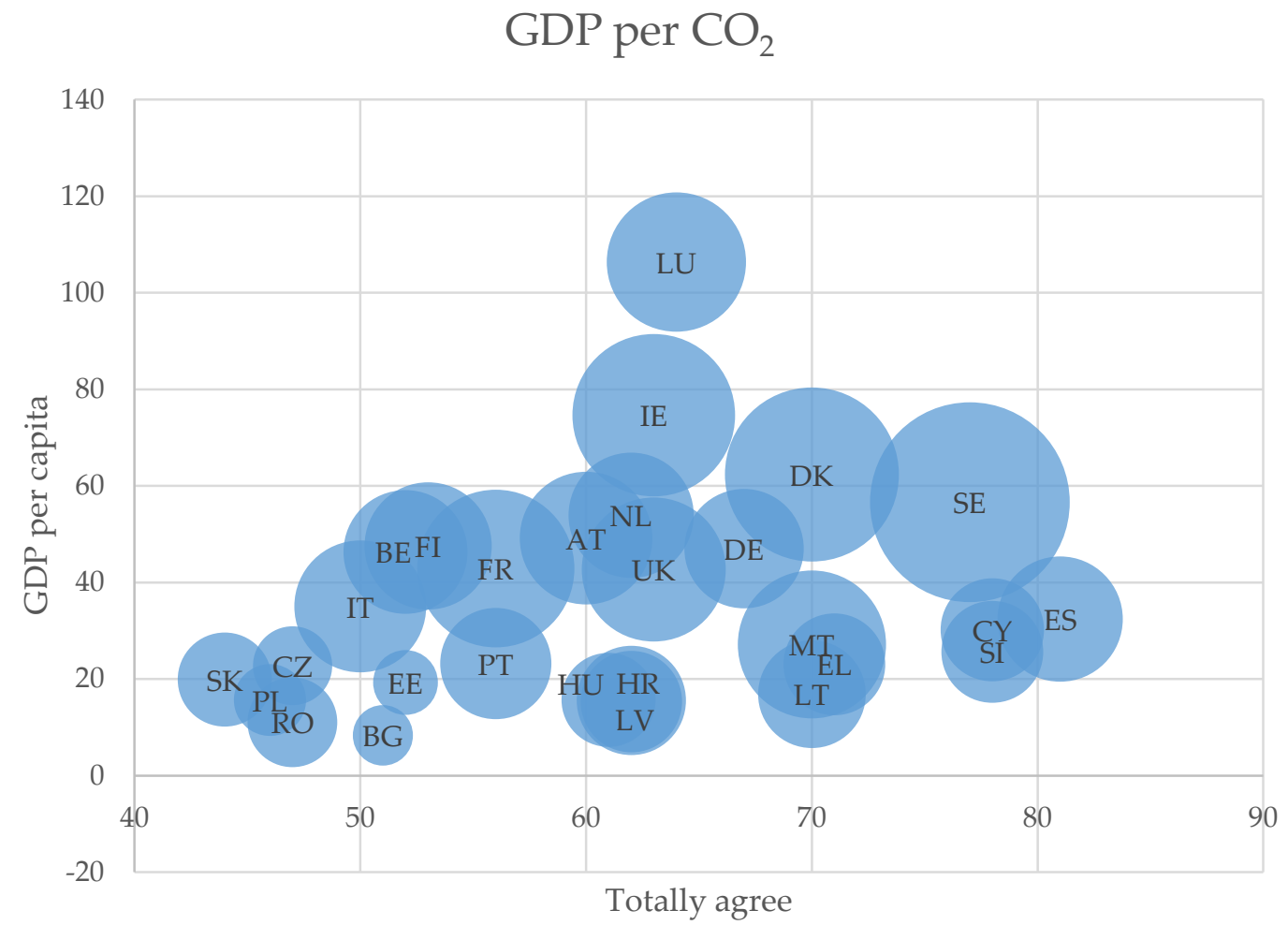

Figure 4. GDP per $\mathrm{CO}_{2}$ with relation to GDP per capita and the percentage of respondents who totally agreed with the statement about the EU's responsibility. 


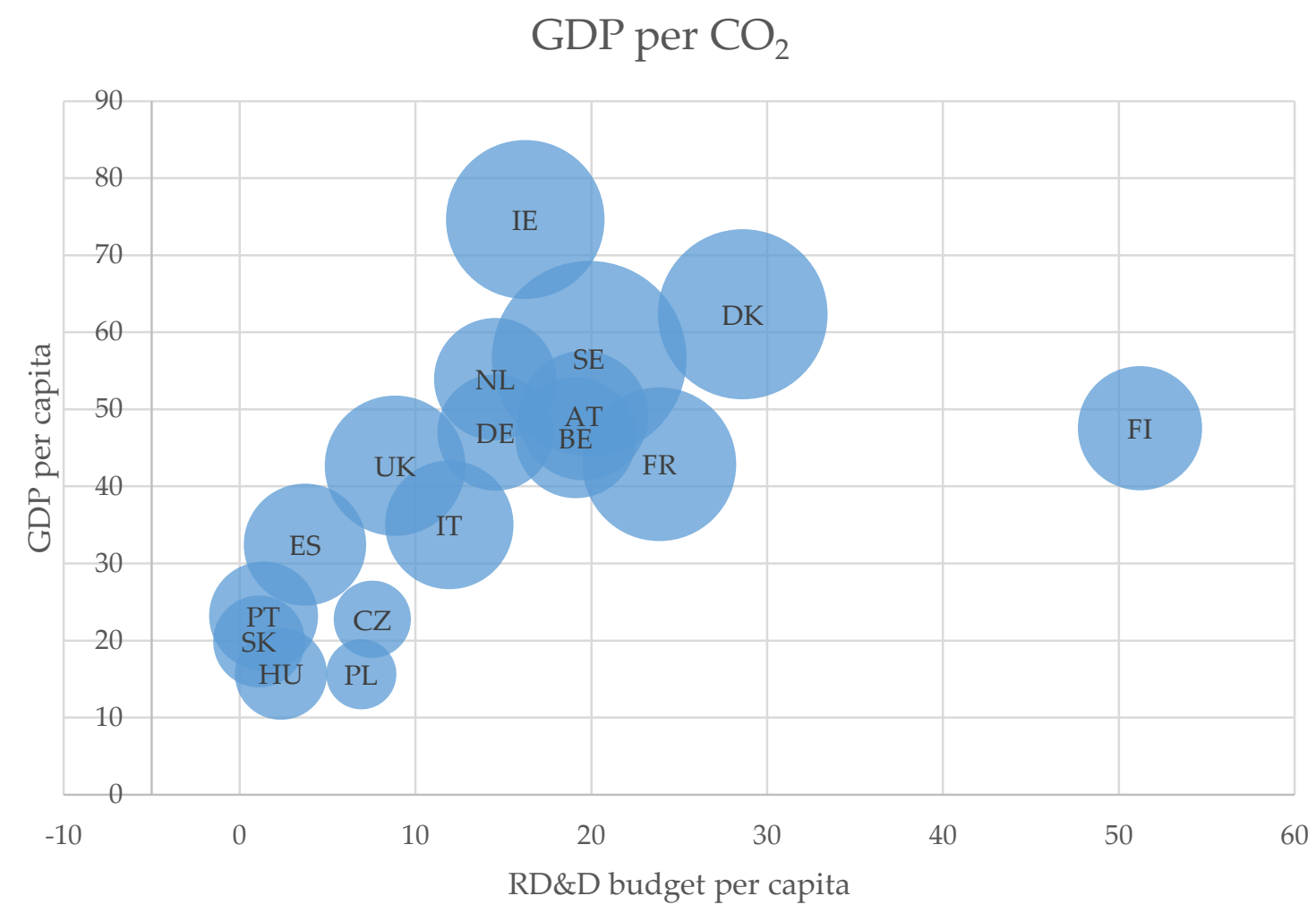

Figure 5. GDP per $\mathrm{CO}_{2}$ with relation to GDP per capita and RD\&D budget per capita.

Apart from an obvious linear relationship between $\mathrm{CO}_{2}$, population and GDP, a small but statistically significant relationship was found between GDP per $\mathrm{CO}_{2}$ and the total agreement to encourage more investment in energy research and innovation. This relationship justifies the consideration of the opinion in the evaluation of a low-carbon economy. Also, there is a noticeable correlation between GDP per capita and RD\&D per capita, which indicates that higher spending in wealthier states could achieve lower emissions per GDP.

The charts in Figures 4 and 5 visualize the relationships between considered variables of EU states. In both figures, SE positively stands out: high social awareness and the above-average standard of living are reflected in a low-carbon economy. However, LU demonstrates that GDP per capita does not always determine the level of GDP per $\mathrm{CO}_{2}$. FR shows that high GDP per $\mathrm{CO}_{2}$ can be reached having a moderate social agreement. MT demonstrates that the same can be done with a below-average GDP per capita. ES, CY, and SI are examples indicating that eco-awareness can precede the results of actions aimed at low $\mathrm{CO}_{2}$ emissions. At the other end are the countries of Central and Eastern Europe (PL, RO, $\mathrm{CZ}$, SK) with a low agreement to the need for investment, low GDP per capita, and high current $\mathrm{CO}_{2}$ emissions per GDP. Figure 5 depicts the general relationship, i.e., the higher GDP per capita, the higher is RD\&D expenditure. However, it also indicates that the current RD\&D budget does not always directly relate to achievements (in the case of FI).

\subsection{Data Analysis}

The results of applied DEA models are presented in Tables 6 and 7 and Figures 6 and 7. BCC-O corresponds to model (1), Ratio DEA—(2), Rough BCC DEA—-(7, 8), and Network Rough BCC DEA—(9) with the rough concept $(7,8)$. DEA model scores based on only hard data GDP per capita and GDP per $\mathrm{CO}_{2}$ without a qualitative variable was also presented (Ratio DEA only hard data). 
Table 6. Progress of the EU toward achieving sustainable development goals—DEA and Rough DEA models.

\begin{tabular}{|c|c|c|c|c|c|c|c|}
\hline Country & $\begin{array}{c}\text { Ratio DEA only } \\
\text { Hard Data } \\
\phi\end{array}$ & $\begin{array}{c}\text { BCC-O } \\
\phi\end{array}$ & $\begin{array}{c}\text { Ratio DEA Model } \\
\text { (non-Linear) } \\
\phi\end{array}$ & \multicolumn{2}{|c|}{$\begin{array}{c}\text { Rough BCC DEA Model } \\
\alpha=0.6\end{array}$} & \multicolumn{2}{|c|}{$\begin{array}{c}\text { Rough BCC DEA Model } \\
\alpha=0.8\end{array}$} \\
\hline AT Austria & $49.1 \%$ & $63.6 \%$ & $69.8 \%$ & $54.0 \%$ & $99.7 \%$ & $49.7 \%$ & $100.0 \%$ \\
\hline BG Bulgaria & $100.0 \%$ & $100.0 \%$ & $100.0 \%$ & $100.0 \%$ & $100.0 \%$ & $100.0 \%$ & $100.0 \%$ \\
\hline CY Cyprus & $44.4 \%$ & $44.9 \%$ & $44.4 \%$ & $44.9 \%$ & $45.4 \%$ & $44.9 \%$ & $48.8 \%$ \\
\hline CZ Czechia & $34.7 \%$ & $52.6 \%$ & $43.1 \%$ & $37.2 \%$ & $100.0 \%$ & $34.4 \%$ & $100.0 \%$ \\
\hline EE Estonia & $27.9 \%$ & $30.8 \%$ & $31.0 \%$ & $27.6 \%$ & $38.7 \%$ & $27.6 \%$ & $100.0 \%$ \\
\hline EL Greece & $56.6 \%$ & $56.1 \%$ & $56.6 \%$ & $56.1 \%$ & $56.1 \%$ & $56.1 \%$ & $62.7 \%$ \\
\hline ES Spain & $61.5 \%$ & $62.4 \%$ & $61.5 \%$ & $62.4 \%$ & $62.4 \%$ & $62.4 \%$ & $65.8 \%$ \\
\hline FI Finland & $46.5 \%$ & $76.9 \%$ & $66.9 \%$ & $51.0 \%$ & $100.0 \%$ & $47.2 \%$ & $100.0 \%$ \\
\hline FR France & $77.1 \%$ & $100.0 \%$ & $100.0 \%$ & $82.5 \%$ & $100.0 \%$ & $78.6 \%$ & $100.0 \%$ \\
\hline HR Croatia & $87.9 \%$ & $87.6 \%$ & $87.9 \%$ & $87.6 \%$ & $87.6 \%$ & $87.6 \%$ & $100.0 \%$ \\
\hline LU Luxembourg & $48.7 \%$ & $63.6 \%$ & $67.4 \%$ & $51.4 \%$ & $79.3 \%$ & $48.7 \%$ & $100.0 \%$ \\
\hline LV Latvia & $63.5 \%$ & $99.7 \%$ & $100.0 \%$ & $99.7 \%$ & $99.7 \%$ & $99.7 \%$ & $100.0 \%$ \\
\hline MT Malta & $100.0 \%$ & $100.0 \%$ & $100.0 \%$ & $100.0 \%$ & $100.0 \%$ & $100.0 \%$ & $100.0 \%$ \\
\hline NL The Netherlands & $40.7 \%$ & $53.8 \%$ & $58.1 \%$ & $45.6 \%$ & $77.8 \%$ & $40.9 \%$ & $100.0 \%$ \\
\hline PL Poland & $43.2 \%$ & $58.5 \%$ & $56.7 \%$ & $43.1 \%$ & $100.0 \%$ & $43.1 \%$ & $100.0 \%$ \\
\hline PT Portugal & $67.4 \%$ & $74.1 \%$ & $76.9 \%$ & $66.9 \%$ & $73.3 \%$ & $66.9 \%$ & $100.0 \%$ \\
\hline RO Romania & $100.0 \%$ & $100.0 \%$ & $100.0 \%$ & $100.0 \%$ & $100.0 \%$ & $100.0 \%$ & $100.0 \%$ \\
\hline SE Sweden & $100.0 \%$ & $100.0 \%$ & $100.0 \%$ & $100.0 \%$ & $100.0 \%$ & $100.0 \%$ & $100.0 \%$ \\
\hline SI Slovenia & $50.6 \%$ & $50.4 \%$ & $50.6 \%$ & $50.4 \%$ & $50.4 \%$ & $50.4 \%$ & $54.4 \%$ \\
\hline SK Slovakia & $57.0 \%$ & $100.0 \%$ & $100.0 \%$ & $56.8 \%$ & $100.0 \%$ & $56.4 \%$ & $100.0 \%$ \\
\hline UK United Kingdom & $64.7 \%$ & $74.2 \%$ & $77.6 \%$ & $67.5 \%$ & $98.4 \%$ & $66.0 \%$ & $100.0 \%$ \\
\hline
\end{tabular}


Table 7. Progress of the EU toward achieving sustainable development goals-Network DEA model.

\begin{tabular}{lcccc}
\hline \multirow{2}{*}{ Country } & \multicolumn{3}{c}{ Network Rough BCC DEA Model } \\
& $\boldsymbol{\phi}_{1}^{\text {inf }(\alpha)}$ & $\boldsymbol{\phi}_{1}^{\text {sup }(\alpha)}$ & $\boldsymbol{\phi}_{2}^{\text {inf }(\alpha)}$ & $\boldsymbol{\phi}_{2}^{\text {sup }(\alpha)}$ \\
\hline AT Austria & $82.2 \%$ & $98.8 \%$ & $44.1 \%$ & $44.1 \%$ \\
BE Belgium & $81.8 \%$ & $100.0 \%$ & $38.5 \%$ & $39.6 \%$ \\
CZ Czechia & $100.0 \%$ & $100.0 \%$ & $17.7 \%$ & $28.9 \%$ \\
DE Germany & $77.0 \%$ & $91.4 \%$ & $35.7 \%$ & $35.7 \%$ \\
DK Denmark & $76.4 \%$ & $89.8 \%$ & $76.0 \%$ & $76.0 \%$ \\
ES Spain & $77.0 \%$ & $82.7 \%$ & $39.4 \%$ & $39.4 \%$ \\
FI Finland & $85.5 \%$ & $99.4 \%$ & $40.7 \%$ & $40.7 \%$ \\
FR France & $83.3 \%$ & $99.6 \%$ & $62.1 \%$ & $62.1 \%$ \\
HU Hungary & $100.0 \%$ & $100.0 \%$ & $42.6 \%$ & $63.7 \%$ \\
IE Ireland & $76.8 \%$ & $92.8 \%$ & $66.3 \%$ & $66.3 \%$ \\
IT Italy & $86.7 \%$ & $100.0 \%$ & $43.6 \%$ & $61.9 \%$ \\
NL & $80.8 \%$ & $96.7 \%$ & $39.3 \%$ & $39.3 \%$ \\
The Netherlands & $100.0 \%$ & $100.0 \%$ & $25.1 \%$ & $25.1 \%$ \\
PL Poland & $100.0 \%$ & $100.0 \%$ & $34.3 \%$ & $36.7 \%$ \\
PT Portugal & $72.9 \%$ & $84.4 \%$ & $100.0 \%$ & $100.0 \%$ \\
SE Sweden & $100.0 \%$ & $100.0 \%$ & $30.1 \%$ & $100.0 \%$ \\
SK Slovakia & $80.3 \%$ & $95.9 \%$ & $51.9 \%$ & $51.9 \%$ \\
UK United & & & & \\
Kingdom & & & & \\
\hline
\end{tabular}

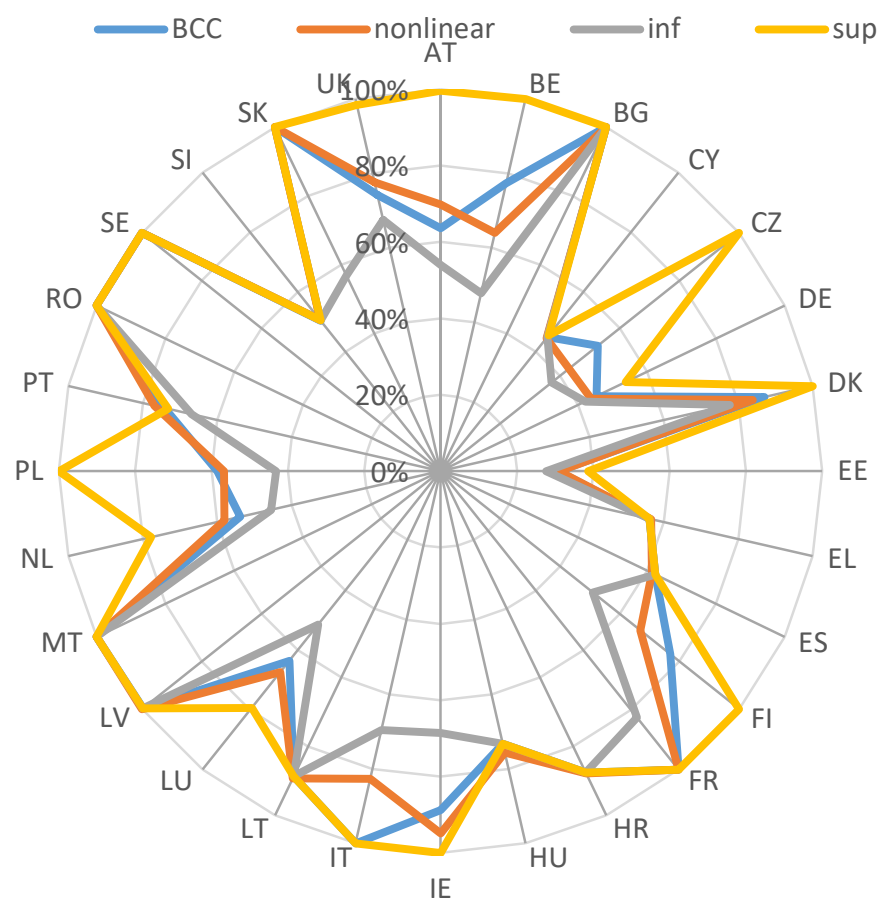

Figure 6. Visualization of the scores-DEA and Rough DEA $(\alpha=0.6)$. 


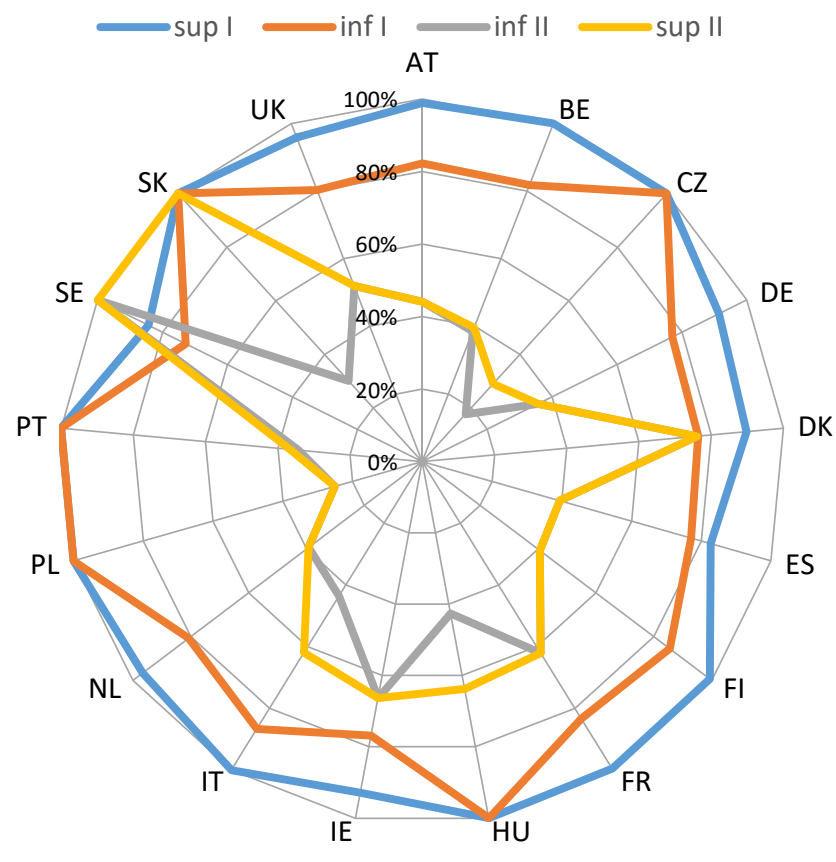

Figure 7. Visualization of the scores-Rough network DEA $(\alpha=0.6)$.

Including additional variables in DEA increase or leave the rating unchanged. Assessment with both quantitative and qualitative variables is less strict. It is worth noting that the assessment based only on quantitative data is close to the pessimistic estimation from the Rough BCC DEA model integrating soft and hard data for $\alpha=0.8$.

Differences between nonlinear and traditional BCC approaches are insubstantial. The highest scores by these models (1) and (2) are obtained by representatives of various groups of countries:

- $\quad$ SE-the leader, which obtains the high score despite high social awareness and the high GDP per capita;

- $\quad$ FR and IT-with above average GDP per capita and under average agreement;

- $\mathrm{RO}, \mathrm{BG}$, and SK - where the score is due to low GDP per capita and low agreement;

- MT-despite a high agreement with average GDP per capita;

- $\quad$ LV—with an average agreement but low GDP per capita.

The incorporation of inconsistency in opinions broadens the range of scores. The $100 \%$ effective countries may also be countries, which by models (1) or (2) achieved high nearly $100 \%$ result, i.e., (i) IE or DK, but also those having average results, namely, (ii) BE and FI, or even low results, i.e., (iii) CZ or PL. It is significant that in the case of groups (i) and (ii), the dispersion between optimistic and pessimistic results is large, around $50 \%$.

The two-stage network evaluation shows a relatively high efficiency of the first stage- the transformation of GDP per capita and public awareness into the RD\&D budget. Results of the second stage indicate the need for much improvement in expenditure efficiency. However, these conclusions should be made with caution as financial expenses often have an effect in the long term.

The provided example of assessing the performance of sustainable development of EU countries indicates that depending on the assumed interpretation of qualitative data, varying scores can sometimes be obtained. Four groups of EU countries can be distinguished based on the Rough BCC DEA model:

- $\quad$ with stabile, equal pessimistic, and optimistic results: BG, CY, EL, ES, HR, HU, LT, LV, MT, RO, SE, SI, PT;

- $\quad$ with small, less than 0.2 , differences: DE, EE, FR; 
- $\quad$ with average, from 0.2 to 0.4 , differences: DK, IE, IT, LU, NL, UK;

- $\quad$ with extreme, over 0.4 , differences: AT, BE, CZ, FI, PL, SK.

The final assessment may consist of an average score with a range of possible results. The width of the assessment range represents its sensitivity to changes in data interpretation.

\section{Discussion}

The contribution of the article is two-fold. First, it presented a new hybrid model based on a combination of Rough Sets and DEA. The model is intended for the integration of hard and soft data in the object ranking task. It enables the inclusion of uncertainty in the underlying data. Second, the article demonstrated the use of the Rough DEA model by assessing EU countries in terms of their progress toward sustainable development objectives. It allows the assessment of physical data and socio-economic data and permits for a more multi-faceted and objective evaluation. The paper is also significant because both quantitative and qualitative data were used to appraise the performance of countries in the field of sustainable development.

Sustainable development goals address many global challenges, including those related to poverty and social inequalities [3], exploitation of natural resources, growing global population, and energy needs [92], and the aging society in the EU [93]. The article refers to the monitoring of clean energy goals considering investments in technology development and modernization at a given level of economic growth and social support.

The article is particularly relevant under the present circumstances. The period chosen for the analysis precedes the anticipated global economic crisis, which will hit many countries that were most affected by COVID-19. In their efforts to reduce $\mathrm{CO}_{2}$ emissions, government-level decision-makers will have to focus more on the economic opportunities of individual countries and public opinion.

The assessment of the EU's progress toward sustainable development goals was based on hard and soft data integration. It can be treated as a preliminary stage of quantitative considerations regarding the need to increase ecological awareness, shaping the sense of responsibility and readiness to bear the costs of eco-development. The used approach allows broadening the perspective and provides more reliable sustainability rankings. The presented studies did not fully explore the broad research topics of the subject. In future research, it is worth designing a dedicated survey for the measurement of the degree of social readiness to incur expenses of transformation into a low-carbon economy. However, the most important extension of the presented models is the inclusion of a time delay between expenditure, social readiness, and quantitative indicators of sustainability. This task should comprise an adequate aggregation of data according to the schedule of research and investment processes.

Author Contributions: J.N. and E.C. were responsible for the study conception and design; E.C. performed computation and analysis; J.N. was responsible for data interpretation; J.N. and E.C. discussed the results and contributed to the final manuscript. All authors have read and agreed to the published version of the manuscript.

Funding: This research was conducted within the framework of the project No. WZ/WIZ/1/2019 of the Bialystok University of Technology and financed from the subsidy granted by the Minister of Science and Higher Education.

Conflicts of Interest: The authors declare no conflicts of interest. The funders had no role in the design of the study; in the collection, analyses, or interpretation of data; in the writing of the manuscript, or in the decision to publish the results.

\section{Abbreviations}

$\begin{array}{ll}\text { AT } & \text { Austria } \\ \text { BE } & \text { Belgium } \\ \text { BG } & \text { Bulgaria } \\ \text { CY } & \text { Cyprus } \\ \text { CZ } & \text { Czechia } \\ \text { DE } & \text { Germany } \\ \text { DK } & \text { Denmark }\end{array}$




$\begin{array}{ll}\text { EE } & \text { Estonia } \\ \text { EL } & \text { Greece } \\ \text { ES } & \text { Spain } \\ \text { FI } & \text { Finland } \\ \text { FR } & \text { France } \\ \text { HR } & \text { Croatia } \\ \text { HU } & \text { Hungary } \\ \text { IE } & \text { Ireland } \\ \text { IT } & \text { Italy } \\ \text { LT } & \text { Lithuania } \\ \text { LV } & \text { Latvia } \\ \text { LU } & \text { Luxembourg } \\ \text { MT } & \text { Malta } \\ \text { NL } & \text { The Netherlands } \\ \text { PT } & \text { Portugal } \\ \text { PL } & \text { Poland } \\ \text { RO } & \text { Romania } \\ \text { SE } & \text { Sweden } \\ \text { SI } & \text { Slovenia } \\ \text { SK } & \text { Slovakia } \\ \text { UK } & \text { United Kingdom }\end{array}$

\section{References}

1. Mavi, N.K.; Mavi, R.K. Energy and environmental efficiency of OECD countries in the context of the circular economy: Common weight analysis for Malmquist productivity index. J. Environ. Manag. 2019, 247, 651-661. [CrossRef]

2. Foresight 2020. ISI Emerging Markets Report; ISI Emerging Market Group: London, UK, 2019; Available online: https://info.ceicdata.com/isi-group-foresight-2019-report-download (accessed on 4 April 2020).

3. UN General Assembly, Transforming our world: The 2030 Agenda for Sustainable Development, 21 October 2015, A/RES/70/1. Available online: https://www.refworld.org/docid/57b6e3e44.html (accessed on 4 April 2020).

4. Siksnelyte, I.; Zavadskas, E.K. Achievements of the European Union Countries in Seeking a Sustainable Electricity Sector. Energies 2019, 12, 2254. [CrossRef]

5. Malinauskaite, J.; Jouhara, H.; Ahmad, L.; Milani, M.; Montorsi, L.; Venturelli, M. Energy efficiency in industry: EU and national policies in Italy and the UK. Energy 2019, 172, 255-269. [CrossRef]

6. Lindberg, M.B.; Markard, J.; Andersen, A.D. Policies, actors and sustainability transition pathways: A study of the EU's energy policy mix. Res. Policy 2019, 48, 103668. [CrossRef]

7. Nazarko, L.; Melnikas, B. Operationalising Responsible Research and Innovation - tools for enterprises. Eng. Manag. Prod. Serv. 2019, 11, 21-28. [CrossRef]

8. Nazarko, L. Responsible Research and Innovation in Enterprises: Benefits, Barriers and the Problem of Assessment. J. Open Innov. Technol. Mark. Complex 2020, 6, 12. [CrossRef]

9. Nazarko, Ł. Future-Oriented Technology Assessment. Proced. Eng. 2017, 182, 504-509. [CrossRef]

10. International Energy Agency (IEA). Available online: https://www.iea.org (accessed on 4 April 2020).

11. Cîrstea, S.; Moldovan-Teselios, C.; Cîrstea, A.; Turcu, A.; Darab, C. Evaluating Renewable Energy Sustainability by Composite Index. Sustainability 2018, 10, 811. [CrossRef]

12. Momete, D. Measuring Renewable Energy Development in the Eastern Bloc of the European Union. Energies 2017, 10, 2120. [CrossRef]

13. Arbolino, R.; Boffardi, R.; De Simone, L.; Ioppolo, G. Who achieves the efficiency? A new approach to measure "local energy efficiency.". Ecol. Ind. 2020, 110, 105875. [CrossRef]

14. Kaplinski, O.; Peldschus, F.; Nazarko, J.; Kaklauskas, A.; Baušys, R. MCDM, operational research and sustainable development in the trans-border Lithuanian-German- Polish co-operation. Eng. Manag. Prod. Serv. 2019, 11, 7-18. [CrossRef] 
15. Papież, M.; Śmiech, S.; Frodyma, K. Determinants of renewable energy development in the EU countries. A 20-year perspective. Renew. Sustain. Energy Rev. 2018, 91, 918-934. [CrossRef]

16. Pietrapertosa, F.; Khokhlov, V.; Salvia, M.; Cosmi, C. Climate change adaptation policies and plans: A survey in 11 South East European countries. Renew. Sustain. Energy Rev. 2018, 81, 3041-3050. [CrossRef]

17. Holma, A.; Leskinen, P.; Myllyviita, T.; Manninen, K.; Sokka, L.; Sinkko, T.; Pasanen, K. Environmental impacts and risks of the national renewable energy targets-A review and a qualitative case study from Finland. Renew. Sustain. Energy Rev. 2018, 82, 1433-1441. [CrossRef]

18. Neofytou, H.; Karakosta, C.; Gómez, N.C. Impact Assessment of Climate and Energy Policy Scenarios: A Multi-Criteria Approach. In Understanding Risks and Uncertainties in Energy and Climate Policy; Doukas, H., Flamos, A., Lieu, J., Eds.; Springer International Publishing: Cham, Germany, 2019; pp. 123-142. ISBN 978-3-030-03151-0.

19. Bigerna, S.; Andrea Bollino, C.; Micheli, S. Costs assessments of European environmental policies. Comput. Oper. Res. 2016, 66, 327-335. [CrossRef]

20. D'Adamo, I.; Rosa, P. Current state of renewable energies performances in the European Union: A new reference framework. Energy Convers. Manag. 2016, 121, 84-92. [CrossRef]

21. Duscha, V.; Fougeyrollas, A.; Nathani, C.; Pfaff, M.; Ragwitz, M.; Resch, G.; Schade, W.; Breitschopf, B.; Walz, R. Renewable energy deployment in Europe up to 2030 and the aim of a triple dividend. Energy Policy 2016, 95, 314-323. [CrossRef]

22. DeLlano-Paz, F.; Martínez Fernandez, P.; Soares, I. Addressing 2030 EU policy framework for energy and climate: Cost, risk and energy security issues. Energy 2016, 115, 1347-1360. [CrossRef]

23. Pacesila, M.; Burcea, S.G.; Colesca, S.E. Analysis of renewable energies in European Union. Renew. Sustain. Energy Rev. 2016, 56, 156-170. [CrossRef]

24. Cilinskis, E.; Indzere, Z.; Blumberga, D. Prioritization methodology for the determination of national targets. Energy Proced. 2017, 128, 215-221. [CrossRef]

25. Nikolaev, A.; Konidari, P. Development and assessment of renewable energy policy scenarios by 2030 for Bulgaria. Renew. Energy 2017, 111, 792-802. [CrossRef]

26. Capros, P.; Kannavou, M.; Evangelopoulou, S.; Petropoulos, A.; Siskos, P.; Tasios, N.; Zazias, G.; DeVita, A. Outlook of the EU energy system up to 2050: The case of scenarios prepared for European Commission's "clean energy for all Europeans" package using the PRIMES model. Energy Strategy Rev. 2018, 22, 255-263. [CrossRef]

27. Radulescu, M.; Fedajev, A.; Sinisi, C.; Popescu, C.; Iacob, S. Europe 2020 Implementation as Driver of Economic Performance and Competitiveness. Panel Analysis of CEE Countries. Sustainability 2018, 10, 566. [CrossRef]

28. Soava, G.; Mehedintu, A.; Sterpu, M.; Raduteanu, M. Impact of Renewable Energy Consumption on Economic Growth: Evidence from European Union Countries. Technol. Econ. Dev. Econ. 2018, 24, 914-932. [CrossRef]

29. Arbolino, R.; Boffardi, R.; Ioppolo, G. The effectiveness of European energy policy on the Italian system: Regional evidences from a hierarchical cluster analysis approach. Energy Policy 2019, 132, 47-61. [CrossRef]

30. Bórawski, P.; Bełdycka-Bórawska, A.; Szymańska, E.J.; Jankowski, K.J.; Dubis, B.; Dunn, J.W. Development of renewable energy sources market and biofuels in The European Union. J. Clean. Prod. 2019, 228, 467-484. [CrossRef]

31. Brożyna, J.; Mentel, G.; Ivanová, E.; Sorokin, G. Classification of Renewable Sources of Electricity in the Context of Sustainable Development of the New EU Member States. Energies 2019, 12, 2271. [CrossRef]

32. Cirstea, S.D.; Tiron-Tudor, A.; Nistor, R.L.; Cirstea, A.; Fulop, M.T. Renewable Energy and Economic Development 'Distances' in Eastern Europe. J. Environ. Prot. Ecol. 2019, 20, 254-264.

33. Lyeonov, S.; Pimonenko, T.; Bilan, Y.; Štreimikienè, D.; Mentel, G. Assessment of Green Investments' Impact on Sustainable Development: Linking Gross Domestic Product Per Capita, Greenhouse Gas Emissions and Renewable Energy. Energies 2019, 12, 3891. [CrossRef]

34. Mikalauskiene, A.; Štreimikis, J.; Mikalauskas, I.; Stankūnienė, G.; Dapkus, R. Comparative Assessment of Climate Change Mitigation Policies in Fuel Combustion Sector of Lithuania and Bulgaria. Energies 2019, 12, 529. [CrossRef]

35. Pach-Gurgul, A.; Ulbrych, M. Progress of the V4 Countries towards the EU's Energy and Climate Targets in the Context of Energy Security Improvement. EBER 2019, 7, 175-197. [CrossRef] 
36. Siksnelyte, I.; Zavadskas, E.K.; Bausys, R.; Streimikiene, D. Implementation of EU energy policy priorities in the Baltic Sea Region countries: Sustainability assessment based on neutrosophic MULTIMOORA method. Energy Policy 2019, 125, 90-102. [CrossRef]

37. Fedajev, A.; Stanujkic, D.; Karabašević, D.; Brauers, W.K.M.; Zavadskas, E.K. Assessment of progress towards "Europe 2020" strategy targets by using the MULTIMOORA method and the Shannon Entropy Index. J. Clean. Prod. 2020, 244, 118895. [CrossRef]

38. Swain, R.B.; Karimu, A. Renewable electricity and sustainable development goals in the EU. World Dev. 2020, 125, 104693. [CrossRef]

39. Chodakowska, E.; Nazarko, J. Hybrid Rough Set and Data Envelopment Analysis Approach to Technology Prioritisation. Technol. Econ. Dev. Econ. 2020, 26, 1-22. [CrossRef]

40. Chodakowska, E.; Nazarko, J. Environmental DEA Method for Assessing Productivity of European Countries. Technol. Econ. Dev. Econ. 2017, 23, 589-607. [CrossRef]

41. Grochová, L.I.; Myšková, K. How Efficiently are The EU Countries Coping with the Discrepancy Between Economic and Environmental Goals. Soc. Econ. 2016, 38, 319-329. [CrossRef]

42. Iftikhar, Y.; He, W.; Wang, Z. Energy and $\mathrm{CO}_{2}$ emissions efficiency of major economies: A non-parametric analysis. J. Clean. Prod. 2016, 139, 779-787. [CrossRef]

43. Madaleno, M.; Moutinho, V.; Robaina, M. Economic and Environmental Assessment: EU Cross-country Efficiency Ranking Analysis. Energy Proced. 2016, 106, 134-154. [CrossRef]

44. Sanz, T.; Velasco, F.; Yñiguez, R. Is Spain More Efficient Than the Other Countries of EU-28? Searching the Answer through DEA and Malmquist Index. 2016. Available online: http://ceur-ws.org/Vol-1812/JARCA16paper-7.pdf (accessed on 4 April 2020).

45. Moutinho, V.; Madaleno, M.; Robaina, M. The economic and environmental efficiency assessment in EU cross-country: Evidence from DEA and quantile regression approach. Ecol. Ind. 2017, 78, 85-97. [CrossRef]

46. Gökgöz, F.; Güvercin, M.T. Energy security and renewable energy efficiency in EU. Renew. Sustain. Energy Rev. 2018, 96, 226-239. [CrossRef]

47. Mezősi, A.; Szabó, L.; Szabó, S. Cost-efficiency benchmarking of European renewable electricity support schemes. Renew. Sustain. Energy Rev. 2018, 98, 217-226. [CrossRef]

48. Hsieh, J.; Lu, C.; Li, Y.; Chiu, Y.; Xu, Y. Environmental Assessment of European Union Countries. Energies 2019, 12, 295. [CrossRef]

49. Teng, X.; Lu, L.C.; Chiu, Y.-H. How the European Union reaches the target of $\mathrm{CO}_{2}$ emissions under the Paris Agreement. Eur. Plan. Stud. 2019, 1-22. [CrossRef]

50. Zurano-Cervelló, P.; Pozo, C.; Mateo-Sanz, J.M.; Jiménez, L.; Guillén-Gosálbez, G. Sustainability efficiency assessment of the electricity mix of the 28 EU member countries combining data envelopment analysis and optimized projections. Energy Policy 2019, 134, 110921. [CrossRef]

51. Wernet, G.; Bauer, C.; Steubing, B.; Reinhard, J.; Moreno-Ruiz, E.; Weidema, B. The ecoinvent database version 3 (part I): Overview and methodology. Int. J. Life Cycle Assess. 2016, 21, 1218-1230. [CrossRef]

52. Banker, R.D.; Charnes, A.; Cooper, W.W. Some Models for Estimating Technical and Scale Inefficiencies in Data Envelopment Analysis. Manag. Sci. 1984, 30, 1078-1092. [CrossRef]

53. Charnes, A.; Cooper, W.W.; Rhodes, E. Measuring the efficiency of decision making units. Eur. J. Oper. Res. 1978, 2, 429-444. [CrossRef]

54. A Policy Framework for Climate and Energy in the Period from 2020 to 2030; COM(2014) 15; European Commission: Brussels, Belgium, 2014; Available online: https://eur-lex.europa.eu/legal-content/EN/ALL/?uri=CELEX: 52014DC0015 (accessed on 4 April 2020).

55. Energy Roadmap 2050. In Brochure; European Commission: Brussels, Belgium, 2012; Available online: https://ec.europa.eu/energy/sites/ener/files/documents/2012_energy_roadmap_2050_en_0.pdf (accessed on 4 April 2020).

56. EU Energy 2020 - A Strategy for Competitive, Sustainable and Secure Energy; COM(2010) 639; European Commission: Brussels, Belgium, 2010; Available online: http://eur-lex.europa.eu/LexUriServ/LexUriServ.do? uri=COM:2010:0639:FIN:En:PDF (accessed on 4 April 2020).

57. Clean Energy for All Europeans_-Unlocking Europe's Growth Potential; European Commission: Brussels, Belgium, 2016; Available online: https://ec.europa.eu/commission/presscorner/detail/en/IP_16_4009 (accessed on 4 April 2020). 
58. Guidelines on State aid for Environmental Protection and Energy; European Commission: Brussels, Belgium, 2014; Available online: https://eur-lex.europa.eu/legal-content/EN/ALL/?uri=CELEX:52014XC0628(01) (accessed on 4 April 2020).

59. Climate Action-Paris Agreement; European Commission: Brussels, Belgium, 2015; Available online: https: //ec.europa.eu/clima/policies/international/negotiations/paris_en (accessed on 4 April 2020).

60. Climate and Energy Goals for a Competitive, Secure and Low-Carbon EU Economy; European Commission: Brussels, Belgium, 2014; Available online: https://ec.europa.eu/commission/presscorner/detail/en/IP_14_54 (accessed on 4 April 2020).

61. European Commission. Energy Strategy and Energy Union. Available online: https://ec.europa.eu/energy/ en/topics/energy-strategy-and-energyunion/2030-energy-strategy (accessed on 4 April 2020).

62. A Sustainable European Future: The EU Response to the 2030 Agenda for Sustainable Development; Council of the European Union: Brussels, Belgium, 2017; Available online: https://www.consilium.europa.eu/media/23989/ st10370-en17.pdf (accessed on 4 April 2020).

63. United Nations. The Sustainable Development Goals. Available online: http://www.un.org/ sustainabledevelopment/sustainable-development-goals (accessed on 4 April 2020).

64. Energy Indicators for Sustainable Development: Guidelines and Methodologies, IAEA, Vienna (2005); International Atomic Energy Agency: Vienna, Austria, 2005; Available online: https://www-pub.iaea.org/MTCD/ Publications/PDF/Pub1222_web.pdf (accessed on 4 April 2020).

65. Eurostat. Available online: https://ec.europa.eu/eurostat/home? (accessed on 4 April 2020).

66. The European Environment Agency (EEA). Available online: https://www.eea.europa.eu (accessed on 4 April 2020).

67. Europe 2020 Targets: Statistics and Indicators at EU Level. Available online: https: //ec.europa.eu/info/business-economy-euro/economic-and-fiscal-policy-coordination/eu-economicgovernance-monitoring-prevention-correction_en (accessed on 4 April 2020).

68. The World Bank. Available online: https://www.worldbank.org (accessed on 4 April 2020).

69. The World Energy Council. Available online: https://www.worldenergy.org (accessed on 4 April 2020).

70. European Investment Bank. Available online: https://www.eib.org/en/index.htm (accessed on 4 April 2020).

71. Enerdata, Global Energy Statistical Yearbook. Available online: https://yearbook.enerdata.net (accessed on 4 April 2020).

72. IEA (2019), $\mathrm{CO}_{2}$ Emissions from Fuel Combustion. Available online: https://iea.blob.core.windows.net/ assets/38460ae3-b53d-4d47-af2a-d6180377e2e0/CO2Highlights2019-Excelfile.XLS (accessed on 4 April 2020).

73. Europeans' Attitudes on EU Energy Policy; Special Eurobarometer 492; Survey conducted by Kantar Belgium at the request of the European Commission, Directorate-General for Energy: Brussels, Belgium, 2019. [CrossRef]

74. Cooper, W.W.; Deng, H.; Huang, Z.; Li, S.X. Chance constrained programming approaches to congestion in stochastic data envelopment analysis. Eur. J. Op. Res. 2004, 155, 487-501. [CrossRef]

75. Agarwal, S. Efficiency Measure by Fuzzy Data Envelopment Analysis Model. Fuzzy Inf. Eng. 2014, 6, 59-70. [CrossRef]

76. Emrouznejad, A.; Tavana, M.; Hatami-Marbini, A. The State of the Art in Fuzzy Data Envelopment Analysis. In Performance Measurement with Fuzzy Data Envelopment Analysis; Emrouznejad, A., Tavana, M., Eds.; Studies in Fuzziness and Soft Computing; Springer: Berlin/Heidelberg, Germany, 2014; Volume 309, pp. 1-45. ISBN 978-3-642-41371-1.

77. Kolagar, M.; Hosseini, S.M.H.; Felegari, R.; Fattahi, P. Policy-making for renewable energy sources in search of sustainable development: A hybrid DEA-FBWM approach. Environ. Syst. Decis. 2019, 1-25. [CrossRef]

78. Zeng, Y.; Guo, W.; Zhang, F. Comprehensive evaluation of renewable energy technical plans based on data envelopment analysis. Energy Proced. 2019, 158, 3583-3588. [CrossRef]

79. Atanassov, K. Type-1 Fuzzy Sets and Intuitionistic Fuzzy Sets. Algorithms 2017, 10, 106. [CrossRef]

80. Zimmermann, H.-J. Fuzzy Set Theory-And Its Applications; Springer: Dordrecht, The Netherlands, 2001; ISBN 978-94-010-3870-6.

81. Chodakowska, E. A Hybrid Approach in Future-Oriented Technology Assessment. In Proceedings of the Future Technologies Conference (FTC) 2019; San Francisco, CA, USA, 14-15 November 2019, Arai, K., Bhatia, R., Kapoor, S., Eds.; Advances in Intelligent Systems and Computing; Springer International Publishing: Cham, Germany, 2020; Volume 1069, pp. 512-525. ISBN 978-3-030-32519-0.

82. Farrell, M.J. The Measurement of Productive Efficiency. J. R. Stat. Soc. Ser. A 1957, 120, 253. [CrossRef] 
83. Hollingsworth, B.; Smith, P. Use of ratios in data envelopment analysis. Appl. Econ. Lett. 2003, 10, 733-735. [CrossRef]

84. Hatami-Marbini, A.; Toloo, M. Data envelopment analysis models with ratio data: A revisit. Comput. Ind. Eng. 2019, 133, 331-338. [CrossRef]

85. Emrouznejad, A.; Amin, G.R. DEA models for ratio data: Convexity consideration. Appl. Math. Model. 2009, 33, 486-498. [CrossRef]

86. Olesen, O.B.; Petersen, N.C.; Podinovski, V.V. Efficiency measures and computational approaches for data envelopment analysis models with ratio inputs and outputs. Eur. J. Oper. Res. 2017, 261, 640-655. [CrossRef]

87. Chodakowska, E. Hybrydowy Model Priorytetyzacji Technologii; Oficyna Wydawnicza Politechniki Białostockiej: Białystok, Poland, 2019; ISBN 978-83-65596-90-1.

88. Pawlak, Z. Rough sets. Int. J. Comput. Inf. Sci. 1982, 11, 341-356. [CrossRef]

89. $\mathrm{Xu}, \mathrm{J} . ; \mathrm{Li}, \mathrm{B} . ; \mathrm{Wu}, \mathrm{D}$. Rough data envelopment analysis and its application to supply chain performance evaluation. Int. J. Prod. Econ. 2009, 122, 628-638. [CrossRef]

90. Chodakowska, E.; Nazarko, J. Network DEA Models for Evaluating Couriers and Messengers. Proced. Eng. 2017, 182, 106-111. [CrossRef]

91. Chen, Y.; Zhu, J. Measuring Information Technology's Indirect Impact on Firm Performance. Inf. Technol. Manag. 2004, 5, 9-22. [CrossRef]

92. Nazarko, L. Technology Assessment in Construction Sector as a Strategy towards Sustainability. Proced. Eng. 2015, 122, 290-295. [CrossRef]

93. Ejdys, J.; Halicka, K. Sustainable Adaptation of New Technology-The Case of Humanoids Used for the Care of Older Adults. Sustainability 2018, 10, 3770. [CrossRef]

(C) 2020 by the authors. Licensee MDPI, Basel, Switzerland. This article is an open access article distributed under the terms and conditions of the Creative Commons Attribution (CC BY) license (http://creativecommons.org/licenses/by/4.0/). 